UNIVERSIDADE DE SÃO PAULO

ESCOLA DE ENFERMAGEM

DANILA MARIA BATISTA GUEDES

A EXPERIÊNCIA DE PROFISSIONAIS DA SAÚDE FRENTE À TENTATIVA DE SUICÍDIO EM CRIANÇAS E ADOLESCENTES

SÃO PAULO 
DANILA MARIA BATISTA GUEDES

A EXPERIÊNCIA DE PROFISSIONAIS DA SAÚDE FRENTE À TENTATIVA DE SUICÍDIO EM CRIANÇAS E ADOLESCENTES

Tese apresentada ao Programa de PósGraduação em Enfermagem da Universidade de São Paulo para obtenção do título de Doutor em Ciências.

Área de Concentração: Cuidado em Saúde

Orientadora: Profa. Dra. Lisabelle Mariano Rossato

SÃO PAULO

2020 
AUTORIZO A REPRODUÇÃO E DIVULGAÇÃO TOTAL OU PARCIAL DESTE TRABALHO, POR QUALQUER MEIO CONVENCIONAL OU ELETRÔNICO, PARA FINS DE ESTUDO E PESQUISA, DESDE QUE CITADA A FONTE.

Assinatura:

Data:

O presente trabalho foi realizado com apoio da Coordenação de Aperfeiçoamento de Pessoal de Nível Superior - Brasil (CAPES) - Código de Financiamento 001.

\section{Catalogação na Publicação (CIP) \\ Biblioteca "Wanda de Aguiar Horta" \\ Escola de Enfermagem da Universidade de São Paulo}

Guedes, Danila Maria Batista

A experiência de profissionais de saúde frente à tentativa de suicídio em crianças e adolescentes / Danila Maria Batista Guedes. São Paulo, 2020.

$97 p$.

Tese (Doutorado) - Escola de Enfermagem da Universidade de São Paulo.

Orientadora: Prof. ${ }^{a}$ Dr. ${ }^{a}$ Lisabelle Mariano Rossato

Área de concentração: Cuidado em Saúde

1. Tentativa de suicídio. 2. Crianças. 3. Adolescentes. 4. Enfermagem. I. Título.

Ficha catalográfica elaborada por Fabiana Gulin Longhi (CRB-8: 7257) 
Nome: Danila Maria Batista Guedes

Título: A experiência de profissionais da saúde frente à tentativa de suicídio em crianças e adolescentes

Tese apresentada ao Programa de Pós-Graduação em Enfermagem da Universidade de São Paulo para obtenção do título de Doutor em Ciências.

Aprovado em:

\section{Banca Examinadora}

Orientadora: Profa. Dra. Lisabelle Mariano Rossato

Instituição:

Assinatura:

Prof. Dr. Instituição:

Julgamento Assinatura:

Prof. Dr. Instituição:

Julgamento Assinatura:

Prof. Dr. Instituição: Assinatura: 


\section{DEDICATÓRIA}

Aos meus país, Fátima e Dalton, os maiores incentivadores dos meus planos e sonhos e que nunca mediram esforços para me apoiar e proporcionar todas as condições necessárías para que eu chegasse até aqui. $\mathcal{A}$ vocês minha eterna gratídão e respeito. 


\section{AGRADECIMENTO ESPECIAL}

$\mathcal{A}$ Deus, minha fonte inesgotável de fé e esperança. Obrigada, Senhor, por me fortalecer e me fazer instrumento da Vossa palavra e por demonstrar todos os dias o seu amor por mim. 


\section{AGRADECIMENTOS}

Aos meus pais, Fátima e Dalton, pela dedicação, confíança, paciêncía e incondicional amor. Obrigada por me ensinar o signíficado da familia e que familia linda vocês construiram.

Ao Benoni, obrigada por ser o meu amor. Seu companheirismo, dedicação para comigo e disponibilidade me ajudaram a finalizar mais esta etapa das nossas vidas. Sua disciplina e perseverança me

inspiram.

Aos meus queridos irmãos e amados familiares. Saíbam que os tenho como incentivadores e apoiadores das minhas escolhas, obrigada por tudo e por tanto, sempre!

À professora $\mathcal{D} r^{a}$. Lisabelle Rossato. $\mathcal{N}$ ão tenho palavras para descrever a minha gratidão pela senhora, que desde o inicio da minha trajetóría acadêmica esteve sempre tão solícita e disposta a me ensinar. Obrigada por me receber de coração e braços abertos, entender as minhas dificuldades, me acolher em sua familia e por ser um exemplo de mulher para mim. Obrigada por conduzir este trabalho com competência e paciência, apesar dos percalços no caminho. Simplesmente obrigada, Lisa!

Aos amigos e colegas dos grupos de pesquisa e da pós-graduação. NNão irei me arriscar em citar nomes, pois são muitos e valiosos. Obrigada pela parceria em todos os momentos e por compartilharem comigo suas vidas. Sem dúvida vocês deixaram meu caminho na pósgraduação mais leve e colorido. Muitos levarei pra vida e eles sabem quem são. 
Às $\mathcal{D} r^{a}$. Lucía Sílva, Dra. Maria de Lá Ó Ramallo e ao Dr. Gilberto Prates, membros da banca examinadora do exame de qualificação, agradeço as valiosas orientações e contribuições para com este trabalho. E à Dra. María de Lá Ó agradeço também a dísponibilidade apresentada no inicio do doutorado.

À professora $\mathcal{D} r^{a}$. Elaine Buchhorn agradeço a delicadeza e amizade com as quais sempre me tratou durante minha trajetóría na pósgraduação.

Aos funcionários do Departamento de Enfermagem Materno-Infantil

e Psiquíátrica (INDP) e da Secretaría de Pós-Graduação, agradeço a disponibilidade, respeito e educação com os quais sempre me trataram.

Aos profissionais que participaram do estudo, agradeço a disponibilidade e generosidade de compartitharem comigo suas experiencias.

À Escola de Enfermagem da Universidade de São Paulo, na fígura de todos os docentes e funcionários, obrigada!

À Coordenação de Aperfeiçoamento de Pessoal de Nivel Superior (CAPPS), pela concessão da bolsa de estudos no início do doutorado. 


\section{EPÍGRAFE}

"Tudo tem o seu tempo determinado, e há tempo para todo o propósito debaixo do céu."

(Eclesiastes 3:1) 
Guedes DMB. A experiência de profissionais da saúde frente à tentativa de suicídio em crianças e adolescentes [tese]. São Paulo: Escola de Enfermagem, Universidade de São Paulo; 2020.

\section{RESUMO}

O suicídio, fenômeno complexo e multicausal em que o indivíduo provoca sua própria morte é considerado, nos dias atuais, um problema de saúde pública mundial que atinge todas as faixas etárias. A temática do suicídio em crianças e adolescentes envolve não apenas as famílias, mas também os profissionais de saúde, visto que o número de tentativas está cada vez mais crescente no cotidiano dos serviços de urgência e emergência. Porém, os significados que os profissionais atribuem às experiências frente às tentativas de suicídio de crianças e adolescentes podem influenciar na qualidade dos atendimentos. Nesse contexto, o objetivo geral deste estudo foi compreender a experiência de profissionais da saúde frente à tentativa de suicídio de crianças e adolescentes. Trata-se de uma pesquisa qualitativa realizada com os profissionais que atuam no pronto-socorro infantil de um hospital público de ensino no município de São Paulo. Os referenciais teóricos e metodológicos empregados foram, respectivamente, o Interacionismo Simbólico e a Análise Temática. Participaram do estudo treze profissionais, dentre médicos, enfermeiros, técnicos de enfermagem e assistentes sociais. A análise dos dados possibilitou identificar quatro temas: Atendimento à criança e ao adolescente em tentativa de suicídio no pronto-socorro infantil; Fatores que influenciam a tentativa de suicídio em crianças e adolescentes; Despreparo do profissional para atender crianças e adolescentes em tentativa de suicídio e Significado da experiência do profissional frente à tentativa de suicídio em crianças e adolescentes. Ouvir os profissionais que recebem uma criança e/ou adolescente que tentou o suicídio trouxe inúmeras reflexões. Muitas são as dificuldades que o profissional de saúde enfrenta nos serviços, principalmente serviços públicos de assistência à saúde, porém, em se tratando de casos de saúde mental na população infanto juvenil, é necessário um destaque por parte das instituições, que precisam oferecer 
capacitações aos profissionais de maneira a atender suas necessidades e demandas. Na perspectiva do atendimento às crianças e adolescentes em tentativa de suicídio, o enfermeiro enfrenta o desafio que vai além de salvar a vida desses pacientes, mas que também compreende o acolhimento e o cuidado para com essa população e sua família.

Palavras-chave: Tentativa de suicídio; Criança; Adolescente; Enfermagem. 
Guedes DMB. The experience of health professionals in the face of suicide attempt in children and adolescents [thesis]. São Paulo: Nursing School, University of São Paulo; 2020.

\section{ABSTRACT}

The suicide, a complex and multi-causal phenomenon in which the individual causes his or her own death, is currently considered a worldwide public health problem that affects all age groups. The theme of suicide in children and adolescents involves not only families, but also health professionals, as the number of attempts is increasing in the daily routine of urgent and emergency services. However, the meanings that professionals attribute to experiences in the face of suicide attempts by children and adolescents can influence the quality of care. In this context, the general objective of this study was to understand the experience of health professionals facing the suicide attempt of children and adolescents. This is a qualitative research to be carried out with the professionals who work in the children's emergency department of a public teaching hospital in the city of São Paulo. The theoretical and methodological references used were, respectively, Symbolic Interactionism and Thematic Analysis. Thirteen professionals participated in the study, including doctors, nurses, nursing technicians and social workers. Data analysis made it possible to identify four themes: Assistance to children and adolescents attempting suicide in the children's emergency room; Factors that influence suicide attempt in children and adolescents; Professional's lack of preparation to assist children and adolescents in attempted suicide; Meaning of the professional's experience in the face of suicide attempt in children and adolescents. Listening to professionals who receive a child and / or adolescent who attempted suicide has brought numerous statements. There are many difficulties that health professionals face in services, especially public health care services, however, in the case of mental health cases in the juvenile population, it is necessary to highlight the institutions, which need to offer training to professionals in order to meet your needs and demands. From the perspective of assisting children and adolescents in attempted suicide, the nurse faces the 
challenge that goes beyond saving the lives of these patients, but which also includes welcoming and caring for this population and their family.

Keywords: Suicide attempt; Child; Adolescent; Nursing. 


\section{LISTA DE GRÁFICOS}

Gráfico 1 - Distribuição dos participantes, segundo o sexo. .43

Gráfico 2 - Distribuição dos participantes, segundo a faixa etária .43

Gráfico 3 - Distribuição dos participantes, segundo o tempo de graduado na profissão. 45

Gráfico 4 - Distribuição dos participantes, segundo o tempo de atuação no prontosocorro infantil. .45 


\section{LISTA DE DIAGRAMAS}

Diagrama 1 - Conceitos Fundamentais do Interacionismo Simbólico, segundo Charon (2009). 32

Diagrama 2 - Fases da Análise Temática dos Dados 40

Diagrama 3 - Atendimento à criança e ao adolescente em tentativa de suicídio no pronto-socorro infantil.

Diagrama 4 - Fatores que influenciam a tentativa de suicídio em crianças e adolescentes .54

Diagrama 5 - Despreparo do profissional para atender crianças e adolescentes em tentativa de suicídio 60

Diagrama 6 - Significado da experiência do profissional frente à tentativa de suicídio em crianças e adolescentes. .65 


\section{SUMÁRIO}

\section{APRESENTAÇÃO}

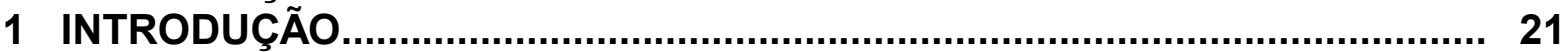

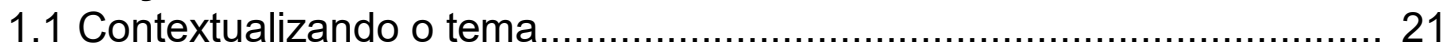

1.2 A tentativa de suicídio em crianças e adolescentes.......................... 23

1.3 Os profissionais de saúde frente à tentativa de suicídio em crianças

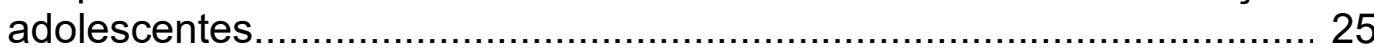

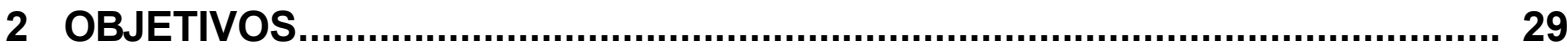

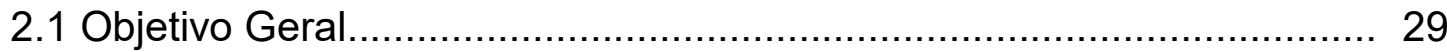

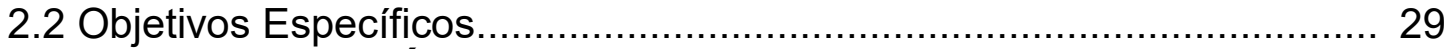

3 PERCURSO METODOLÓGICO................................................................. 31

3.1 Referencial Teórico................................................................. 31

3.2 Referencial Metodológico..................................................... 34

3.3 Desenho do estudo............................................................ 35

3.3.1 Local para realização do estudo....................................... 35

3.3.2 Participantes............................................................. 36

3.3.3 Procedimento para coleta dos dados.................................... 36

3.3.4 Análise e interpretação dos dados..................................... 38

3.4 Aspectos éticos............................................................................ 41

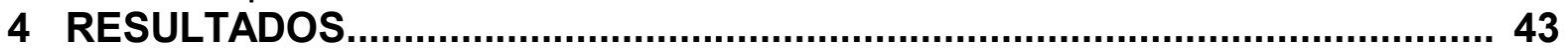

4.1 Contextualização dos participantes.............................................. 43

4.2 A experiência do profissional da saúde frente à tentativa de suicídio em crianças e adolescentes........................................... 45

5 DISCUSSÃO

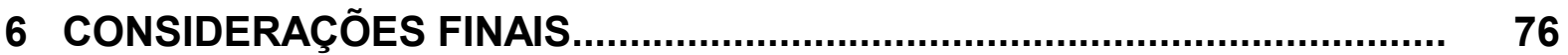

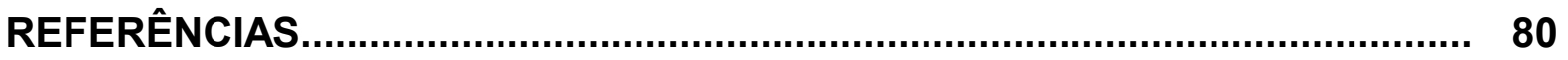

ANEXOS

ANEXO 1 - Aprovação do Comitê de Ética em Pesquisa da Escola de Enfermagem da Universidade de São Paulo

ANEXO 2 - Aprovação do Comitê de Ética em Pesquisa da Instituição APÊNDICES

Coparticipante.................................................................................. 91

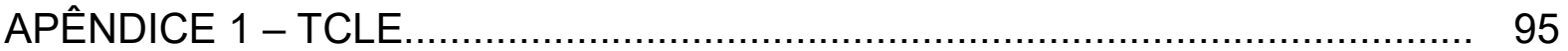

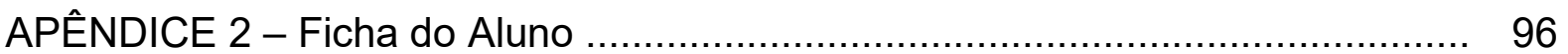




\section{APRESENTAÇÃO}

Foram dias pensando sobre como escrever esta apresentação, narrar fatos da minha vida e os caminhos que percorri. Construir um relato das experiências vividas e rever o passado com os olhos do presente. Somos o lugar onde nos fizemos e as pessoas com quem convivemos.

A enfermagem entrou em minha vida em um momento cheio de incertezas e trouxe consigo toda a maturidade que eu precisava. Foi uma escolha tomada no momento e da maneira certos, nós nos escolhemos, a enfermagem e eu.

Sou Bacharel e Licenciada em Enfermagem pela Universidade Estadual da Paraíba e como aluna bolsista do Programa de Iniciação Científica (PIBIC/CNPq) desenvolvi, durante a graduação, uma pesquisa que teve como objetivo identificar os dez diagnósticos de enfermagem mais frequentes em uma Unidade de Terapia Intensiva Pediátrica em um hospital público. Durante a coleta dos dados, com a realização do exame físico nas crianças, pude vivenciar a rotina de uma unidade pediátrica e compartilhar de momentos alegres e tristes com as crianças e suas famílias.

Dentre os dez diagnósticos de enfermagem que foram identificados, um deles inquietou-me: o diagnóstico de dor aguda. O hospital no qual a pesquisa foi realizada é referência no atendimento de emergência e trauma. Portanto, supõe-se que as crianças que ali estavam internadas, principalmente na UTI, enfrentavam processos dolorosos. Mas o que me impressionou foram as intervenções que eram ou não realizadas quando uma criança estava com dor.

Procurei aprofundar-me na temática da dor infantil e na maneira como ela é avaliada pelo profissional. Essa inquietação, atrelada à minha escolha de fazer uma pós-graduação Stricto Sensu, me trouxe ao mestrado na Escola de Enfermagem da Universidade de São Paulo (EEUSP), especificamente à professora Lisabelle Mariano Rossato.

Concluí o Mestrado em fevereiro de 2016 com a dissertação intitulada "Avaliação da dor de crianças: validação semântica dos Cartões de Qualidade da Dor". No final de março de 2016 fui aprovada no processo seletivo para o Doutorado 
no Programa de Pós-Graduação em Enfermagem da EEUSP com um projeto de pesquisa cuja temática principal continuava a ser a avaliação da dor em pediatria; e em agosto de 2017, na minha busca pelo conhecimento acerca da enfermagem pediátrica, tornei-me especialista em enfermagem pediátrica e neonatal pelo Instituto Israelita de Ensino e Pesquisa Albert Einstein.

Porém, como encontramos na literatura e na fala de alguns mestres, os quais tive a honra de dividir uma sala de aula, o coração do pesquisador é tocado por determinado tema, seja por vivência pessoal/ profissional ou por sensibilidade e interesse.

No mestrado, tive a oportunidade de ser aluna do Programa de Aperfeiçoamento do Ensino (PAE) por dois semestres e durante o doutorado por três, na disciplina ENP0382 - Enfermagem no Cuidado à Criança e Adolescente na Experiência de Doença. Essa experiência permitiu que eu acompanhasse o estágio dos alunos da graduação que é realizado no Instituto da Criança do Hospital das Clínicas da Faculdade de Medicina da Universidade de São Paulo (ICR-HCFMUSP).

Durante esse período estive em contato com crianças, adolescentes e suas famílias que enfrentavam sérios processos patológicos. Nesse tempo, pude observálos e uma situação em especial chamou minha atenção, a de uma adolescente, que chamarei de Marina (nome fictício) nesta narrativa, internada em consequência da sua segunda tentativa de suicídio. O quanto essa situação inquietou-me? Muito.

O estágio aconteceu em novembro de 2017. Em outubro do mesmo ano foi realizado o VII Congresso Brasileiro de Enfermagem Pediátrica e Neonatal, no qual um dos palestrantes internacionais foi o professor Dr Franco Carnevale, da McGill University in Montreal, Canadá, um pesquisador renomado na temática da dor em pediatria. Em uma de suas palestras o professor Franco fez uma abordagem sobre um tema recente a respeito da dor, a dor sofrimento. Dor sofrimento ou Dor total faz referência à dor que transcende a dor fisiológica e entra no quesito sentimentos e, atualmente, está sendo relacionada aos estudos sobre suicídio.

Nesse mesmo período, a professora Lisabelle, minha orientadora, estava começando um grupo de estudos sobre suicídio na infância e na adolescência com algumas enfermeiras pediatras, da área de saúde mental e uma psicóloga. Como 
não tinha relação com o meu tema de pesquisa, que até o momento se tratava da avaliação da dor em crianças transplantadas, relutei em não integrar este grupo. Porém, após minha experiência com Marina e do encontro com o professor Franco escutei minhas angústias, comecei a participar das reuniões do grupo e a buscar na literatura estudos sobre suicídio relacionado à criança e adolescente.

A cada reunião do grupo de estudos questões foram surgindo, quando me dei conta estava inundada por esta temática. Em dezembro de 2017, com o projeto sobre avaliação da dor em crianças transplantadas praticamente pronto para qualificação, li o livro intitulado "Tudo que nunca te contei", da autora Americana Celeste Ng. Trata-se de uma estória sobre o suicídio de uma adolescente e o quanto temos dificuldade em compreender os outros. Terminei o livro em dias, cujo assunto tinha virado meu maior interesse para estudar.

Diante disso, realizei uma revisão na literatura, dialoguei com alguns colegas enfermeiros que trabalham na assistência à criança e ao adolescente que tenta suicídio e percebi junto à professora Lisabelle, a importância em compreender as experiências dos profissionais que recebem uma criança ou um adolescente em uma situação de tentativa de suicídio. 


\section{INTRODUÇÃO}

\subsection{CONTEXTUALIZANDO O TEMA}

O suicídio é o ato em que o indivíduo provoca sua própria morte e refere-se ao desejo consciente de morrer. Trata-se de um fenômeno complexo e multicausal que representa, nos dias atuais, um problema de saúde pública mundial que atinge todas as faixas etárias (Pfeffer, 1997; Kõlves e Leo, 2017; Silva et al., 2017).

O suicídio é a última fase da sequência de acontecimentos do comportamento suicida, que envolve também a tentativa de suicídio, o planejamento e a ideação suicida. A ideação suicida trata-se de pensamentos sobre querer estar morto ou pensamentos sobre tirar a própria vida, não acompanhados por um comportamento de preparação. Já no planejamento, a pessoa toma providências para fazer algum dano que potencialmente tire sua vida (Jans et al., 2017). A tentativa de suicídio, por sua vez, abrange a ação de causar danos a si mesmo, utilizando ou não artifícios secundários como uso abusivo de álcool e medicações, com o intuito de tirar a própria vida, contudo não obtendo o sucesso letal (Organização Mundial de Saúde 2014).

Considerado, atualmente, um problema de saúde pública o suicídio traz consequências sociais, econômicas e políticas, que afetam comunidades, regiões e países. Acomete todas as faixas etárias, sendo ocasionado por um conjunto de fatores biológicos, psicológicos, sociais, econômicos e culturais (Silva et al., 2015; De Sousa et al., 2017). Trata-se do ato de tirar, voluntariamente, a própria vida, com expressivo aumento no número de casos nos últimos anos (Ribeiro et al., 2018), com destaque para o fato de que, a cada 40 segundos, mais de 800.000 pessoas cometem o suicídio (Organização Mundial da Saúde, 2014).

Segundo a Organização Mundial da Saúde (OMS), o suicídio representa 1,4\% de todas as mortes no mundo, tornando-se, em 2012, a $15^{a}$ causa de mortalidade na população geral, estimando-se um aumento para 2,4\% neste ano de 2020, aproximadamente 1,5 milhões de pessoas. Entre os jovens de 15 a 29 anos é a segunda principal causa de morte. Em 2013, a OMS legitimou o primeiro Plano de 
Ação de Saúde Mental, que tem como um dos componentes integrais, a prevenção do suicídio, com o propósito da redução em $10 \%$ da taxa de suicídio nos países até este ano de 2020 (Organização Mundial de Saúde, 2014; Brasil, 2017).

No Brasil, essas taxas variaram de 3,9 a 4,5 para cada 100 mil habitantes, entres os anos de 1994 a 2004, sendo considerada uma taxa geral baixa para a OMS. Em contrapartida, nos dias atuais, o Brasil está entre os dez países com os maiores números de suicídio, com mortalidade de $16,4 \%$ em homens e $24,7 \%$ em mulheres (Brasil, 2017).

Discussões sobre o número de tentativas de suicídio, apesar do baixo número de casos notificados, revelam que as taxas de tentativas de suicídio superam as do suicídio consumado. Um dos motivos para ser considerado um número baixo, devese às subnotificações, classificações errôneas por profissionais, falsificações da causa da morte no atestado de óbito, tabus e preconceitos que podem envolver a moral e a religião das famílias e dos profissionais (Braga e Dell'Aglio, 2013; Kuczynski, 2014; Brasil, 2017).

No Brasil, conforme o Mapa da Violência (Waiselfisz, 2014) publicação baseada em dados coletados pelo Ministério da Saúde no Sistema de Informação sobre Mortalidade (SIM) (Brasil, 2011), entre a população infanto-juvenil foram registrados 105 óbitos por suicídio na faixa etária entre 10 e 14 anos, sendo São Paulo a Unidade da Federação com a maior incidência (17); já na faixa etária entre 15 e 19 anos, 628 jovens cometeram suicídio, dos quais 96 residiam no estado de São Paulo. O Mapa da Violência observou que na faixa etária final da adolescência (15 a 18 anos), houve um aumento de 15,3\% entre 2002 e 2012, passando de 2.515 para 2.900 suicídios (Brasil, 2011; Waiselfisz, 2014).

Diante dessa contextualização estatística, cabe ressaltar que quando dados brasileiros sobre suicídio são analisados, é necessário considerar as altas taxas de subnotificação, que podem ser decorrentes de diversos fatores, como pedido da família para que a causa da morte não seja atestada como suicídio na certidão de óbito e o fato que alguns profissionais de saúde registram de maneira vaga o suicídio, conforme mencionado anteriormente (Araújo, Vieira e Coutinho, 2010; Braga e Dell'Aglio, 2013; Kuczynski, 2014; Silva et al., 2017). 
O exposto evidencia a dificuldade que a temática do suicídio enfrenta em ser abordada adequadamente, mesmo diante de altas taxas estatísticas. É frequente o "mascaramento" sobre este acontecimento, principalmente quando o suicídio acontece na infância e adolescência. Trata-se de um tema permeado por tabus, sob a perspectiva de que a morte possa ser a escolha de uma criança, o que pode promover julgamentos, afetar crenças e religiões, e impedir avaliações imparciais dos profissionais.

\subsection{A TENTATIVA DE SUICÍDIO EM CRIANÇAS E ADOLESCENTES}

Segundo Pfeffer (1997), o comportamento suicida em crianças e adolescentes envolve três definições: a ideação suicida - pensamentos sobre provocar intencionalmente danos ou a morte auto infligidos; a tentativa de suicídio - atos que causem danos; e o suicídio - a morte, propriamente dita.

O suicídio em menores de 15 anos acontece com menor frequência. No entanto, observa-se um aumento deste fenômeno a partir dos 20 anos de idade, sendo em países europeus, asiáticos e nos Estados Unidos a terceira causa de morte entre as crianças e adolescentes de dez a 14 anos. No Brasil, o suicídio na faixa etária entre 15 e 24 anos ocupa o sexto lugar no ranking entre as causas de morte; em menores de 15 anos a porcentagem é estimada entre 0,1 e 0,7\%, sendo observado, porém, um aumento desse número (Kuczynski, 2014; Brasil, 2017).

A infância e adolescência são caracterizadas por constantes mudanças interiores e exteriores que provocam alterações comportamentais, emocionais, físicas e mentais, tornando essas fases da vida mais frágeis e propensas ao comportamento suicida (De Souza et al., 2017). O aumento no número de casos de suicídio e tentativas de suicídio vem ocorrendo ao longo dos anos, colocando crianças e adolescentes em um grupo de risco para a ocorrência de tais fenômenos, já sendo caracterizado, em alguns países, como uma epidemia.

O suicídio dispõe de variados motivos e finalidades atreladas a fatores de risco, como os transtornos psicológicos, aspectos geográficos e culturais, sexualidade e bullying. Entretanto, na contra mão dos fatores de risco, estão os 
fatores de proteção, como a família, os serviços de saúde e o suporte social, com potencial para empreender estratégias de manejos preventivos para o suicídio (Braga e Dell'Aglio, 2013; Silva et al., 2018).

A tentativa de suicídio na infância e adolescência torna-se singular, na medida em que, nesta fase do desenvolvimento, podem aparecer sentimentos intensos de baixa autoestima e mesmo quadros psiquiátricos de grande risco, a exemplo do Transtorno do Déficit de Atenção com Hiperatividade (TDAH) e o transtorno de personalidade antissocial e depressão (Soole, Kõlves, De Leo, 2015; De Sousa et al., 2017).

Atualmente, o bullying, e mais especificamente o cyberbullying, vêm gerando uma ascensão no número de tentativas de suicídios entre crianças e adolescentes, como traz a National Association of School Psychologists (NASP) em um report sobre esta temática. O bullying, definido como atos de violência física ou psicológica, intencionais e repetidos, pode afetar negativamente a vida de crianças e adolescentes e promover desequilíbrios emocionais. Ele não está limitado a essa população específica, mas prevalece entre crianças e adolescentes (Feinberg, Robey, 2010; Lieberman, Cowan, 2011).

Além do bullying e a presença de transtornos psiquiátricos, outros fatores de risco são destacados na literatura (Souza et al., 2010; Braga,Dell'Aglio, 2013; Kuczynski, 2014; Freuchen, Grøholt, 2015; Pereira, Maciel, Guilhermino, 2017; Dos Santos; Leão-Machado, 2019): depressão; abuso de álcool e drogas; abusos físicos, psicológicos ou sexuais;a não convivência com os pares, especialmente na adolescência, com o isolamento social; abandono; suicídio de um membro da família ou do grupo de amigos; homossexualidade; oposição familiar à opção sexual; gravidez na adolescência; decepção amorosa; suporte social deficitário; sentimentos de solidão; rendimento escolar deficiente; dificuldade de aprendizagem; bagagem social e cultural; e à indução por meio das mídias sociais representam, nos dias atuais, os maiores fatores de risco às tentativas de suicídio em crianças e adolescentes.

Ressalta-se que estes fatores não são preditores ao comportamento suicida, porém suas consequências podem aumentar a vulnerabilidade das crianças e dos 
adolescentes às tentativas (Braga, Dell'Aglio, 2013). Nesse sentido, Bertolote, MelloSantos e Botega (2010) destacam a necessidade de capacitação para que os profissionais de saúde identifiquem os fatores de risco frente às tentativas de suicídio e proponham intervenções.

\subsection{OS PROFISSIONAIS DA SAÚDE FRENTE À TENTATIVA DE SUICÍDIO EM CRIANÇAS E ADOLESCENTES}

Como já mencionado no primeiro tópico desta introdução, o suicídio é, hoje, um problema de saúde pública mundial em todas as faixas etárias. A temática do suicídio em crianças e adolescentes envolve não apenas as famílias, mas também os profissionais de saúde, visto que o número de tentativas está cada vez mais crescente no cotidiano dos serviços de urgência e emergência (Freitas, Borges, 2014). Porém, ainda não há uma estrutura de saúde preparada para atender esta demanda crescente nos serviços de urgência e emergência (Kuczynski, 2014).

Estudos revelam que muitos profissionais assumem uma postura discriminatória em relação à tentativa de suicídio (De Sá et al., 2012; Silva et al., 2017) ou têm dificuldade em lidar com seus próprios sentimentos frente a essa situação, principalmente quando envolvem crianças e adolescentes e,Vpor essa razão, resistem em atender demandas como essa (Kuczynski, 2014; Freitas, Borges, 2014).

A assistência prestada em situações que envolvem tentativas de suicídio consiste em ouvir atenciosamente, sem modular os sentimentos e ideias. Por isso, é importante que o profissional transmita ao paciente segurança, o acalme e colabore para que pense e verbalize sobre a pretensão de colocar sua própria vida em risco e o desejo de morrer (Bertolote, Mello-Santos, Botega, 2010). Esses cuidados precisam contemplar a avaliação do estado emocional do paciente e do risco para o suicídio apresentado por ele, o que, consequentemente, implicará na adoção de medidas de vigilância no sentido de evitar novas tentativas de suicídio (Reisdorfer et al., 2015). 
Sob essa perspectiva, protocolos ou instrumentos podem ser implementados na rotina dos serviços de urgência e emergência com o objetivo de auxiliar os profissionais a identificar os fatores de risco e realizar a melhor intervenção. $O$ desenvolvimento desses documentos pode ser com base no manual para a prevenção do suicídio publicado pelo Ministério da Saúde em parceria com a Organização Pan-americana da Saúde (Brasil, 2006) e nas diretrizes práticas para a avaliação e tratamento de pacientes com comportamento suicida publicadas pela Associação Psiquiátrica Americana (American Psychiatric Association, 2003).

Entretanto, para que o profissional consiga aplicar protocolos e prestar um atendimento de qualidade é necessário que os hospitais tenham um ambiente calmo, tranquilo e seguro para assistir um paciente potencialmente suicida. O plano de tratamento precisa ser flexível, considerando sempre o paciente e sua família como um todo, estabelecendo, assim, um cuidado humanizado (Reisdorfer et al., 2015).

Resultados de uma revisão de literatura revelou que há uma escassez de estudos nacionais para formular um protocolo de abordagem e que existe, consequentemente, carência no desenvolvimento de algumas estratégias de intervenções específicas para as pessoas que tentaram suicídio e chegaram aos serviços de emergência (Bertolote, Mello-Santos, Botega, 2010).

A detecção dos fatores pode reduzir o risco de morte iminente referente ao comportamento suicida. Frente a isso, um estudo qualitativo realizado com profissionais de enfermagem concluiu que a constante qualificação, capacitação e busca pelo conhecimento sobre o tema suicídio e seus fatores relacionados possibilitam ao profissional realizar um atendimento mais eficaz a esses indivíduos (Reisdorfer et al., 2015).

Porém, a qualidade dos atendimentos pode ser influenciada por significados que os profissionais atribuem às experiências frente às tentativas de suicídio em crianças e adolescentes. Nesse contexto, a seguinte questão de pesquisa foi formulada: "Qual a experiência dos profissionais da saúde frente à tentativa de suicídio em crianças e adolescentes?". 
Acreditamos que compreender a experiência dos profissionais da saúde frente à tentativa de suicídio de crianças e adolescentes norteará reflexões acerca das suas ações e estratégias, o que promoverá o processo de cuidar nessa perspectiva do suicídio em crianças e adolescentes, justificando a realização deste estudo. 


\section{OBJETIVOS}




\section{OBJETIVOS}

\subsection{GERAL}

- Compreender a experiência de profissionais da saúde frente à tentativa de suicídio em crianças e adolescentes.

\subsection{ESPECÍFICOS}

- Identificar as ações e estratégias desenvolvidas pelos profissionais da saúde no atendimento à tentativa de suicídio de crianças e adolescentes.

- Identificar os fatores que influenciam a tentativa de suicídio de crianças e adolescentes;

- Conhecer os significados atribuídos pelos profissionais da saúde frente à tentativa de suicídio em crianças e adolescentes. 


\section{PERCURSO METODOLÓGICO}




\section{PERCURSO METODOLÓGICO}

Considerando o caráter único da experiência dos profissionais da saúde frente à tentativa de suicídio em crianças e adolescentes, optou-se por desenvolver um estudo qualitativo.

A pesquisa qualitativa é um processo que tem por fim a compreensão de um fenômeno, baseado em diferentes referenciais metodológicos investigativos que explorem um problema social ou humano, consoante o ponto de vista dos sujeitos (Creswell, 2014; Minayo, 2014).

Visando garantir a riqueza e a complexidade da experiência, mediante a pesquisa qualitativa, para responder aos objetivos propostos pretende-se investigar os acontecimentos ocorridos sob a ótica dos próprios autores, do significado que eles atribuem às coisas e às experiências vividas (Minayo, 2014).

\subsection{REFERENCIAL TEÓRICO: O INTERACIONISMO SIMBÓLICO}

O Interacionismo Simbólico surgiu no século XVII e tem suas raízes na Psicologia Social e Sociologia. George Hebert Mead, sociólogo e professor de filosofia na Universidade de Chicago, foi o primeiro a se preocupar com o estudo aprofundado das interações sociais, ampliando e difundindo os conceitos fundamentais deste referencial. Foi ele quem apresentou sistematicamente os pressupostos fundamentais da abordagem interacionista (Charon, 2009).

Um dos propósitos do Interacionismo Simbólico é compreender a causa da ação humana e como os indivíduos agem em relação às suas definições e crenças (Charon, 2009). A escolha deste referencial teórico está relacionada à possibilidade de compreender um determinado evento que, segundo Blumer (1969), é formado a partir da interação entre os indivíduos e essa interação confere sentido ao evento a partir das relações estabelecidas na convivência social.

O Interacionismo Simbólico concentra-se na natureza das interações, na dinâmica das atividades sociais entre as pessoas, no significado dos eventos para as pessoas no mundo em que vivem, nos ambientes naturais de seu cotidiano e nas 
ações por elas desempenhadas (Charon, 2009). Nesse contexto, o ser humano é visto como agente e participante das suas próprias experiências e, ao serem estudados, precisam ser vistos a partir das suas ações (Blumer, 1969).

O Interacionismo Simbólico, segundo Blumer (1969), está fundamentado em três premissas básicas: os seres humanos agem em relação às coisas com base no significado que estas têm para eles; o significado atribuído às coisas é derivado da interação social que os seres humanos estabelecem entre si; os significados são modificados através de um processo interpretativo utilizado pela pessoa ao lidar com as coisas que encontra.

Para melhor compreensão das premissas mencionadas acima, torna-se necessária a compreensão dos seguintes conceitos fundamentais no Interacionismo Simbólico (Charon, 2009): Símbolo, Self, Mente, Assumir o papel do outro, Ação humana, Interação Social (Diagrama 1).

Diagrama 1 - Conceitos Fundamentais do Interacionismo Simbólico, segundo Charon (2009).

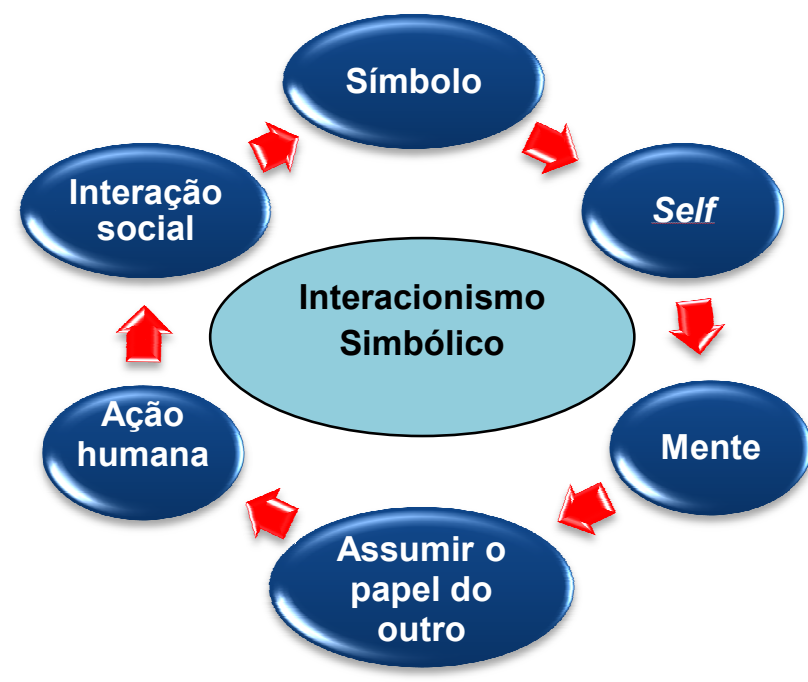

- Símbolo é o conceito central de todo o Interacionismo Simbólico, cujo significado leva à definição. Sem o Símbolo não podemos interagir com os outros e por meio dele o indivíduo pode nomear, memorizar e categorizar objetos; perceber e 
selecionar o que para ele tem significado; comunicar-se consigo próprio; assumir o papel do outro, por ser capaz de transcender o tempo, o espaço e sua própria pessoa (Charon, 2009).

- Self, na perspectiva interacionista, é um objeto social em direção a quem o indivíduo age, ou seja, o indivíduo consegue olhar e se ver, como faz com os outros e consigo. Segundo Charon (2009), o self representa duas vertentes: o "eu" e o "mim", onde o "eu" é a resposta, a tendência espontânea, impulsiva e não socializada que o indivíduo faz uso de forma não intencional, enquanto o "mim" são as atitudes organizadas que determinam a conduta e a interação do indivíduo com o outro.

- Mente é uma atividade, porque é um processo contínuo e ininterrupto que dirige os símbolos em direção ao self. Por meio da mente, a pessoa faz indicações para si, atribui significados e interpreta, dando sentido às coisas em relação ao que foi vivenciado (Charon, 2009).

- Assumir o papel do outro, segundo Charon (2009), é imaginar o mundo a partir da perspectiva do outro. O indivíduo entende o significado das palavras e dos atos das outras pessoas e também é entendido pelos outros.

- Ação humana origina-se das decisões tomadas que resultam em como o indivíduo define sua situação. Por ser um processo simbolicamente construído, Ação humana diz muito a respeito da pessoa que a realiza (Charon, 2009; Blumer, 1969).

- Interação social é a ação de cada indivíduo tendo significado para o ator que a realiza e sendo interpretada por aqueles em direção a quem o ator age. Quando essa ação social se torna mútua, os indivíduos estão engajados em interação social que é simbólica quando, intencionalmente, comunicamos quando agimos e os outros interpretam o que fazemos (Charon, 2009). 


\subsection{REFERENCIAL METODOLÓGICO: ANÁLISE TEMÁTICA}

Como referencial metodológico adotou-se a Análise Temática, um método para identificar, analisar e relatar temas ou padrões que emergem dos dados, o que permite organizá-los e descrevê-los em detalhe, implicando também na interpretação de vários aspectos relacionados com o tema do estudo (Boyatzis, 1998). Segundo Braun e Clarke (2006), a análise temática deveria ser muito mais utilizada nos métodos qualitativos de pesquisa, uma vez que providencia competências que são úteis à condução de outras maneiras de análise qualitativa.

Trata-se de uma abordagem caracterizada pela realização de leituras detalhadas dos dados a fim de chegar a conceitos obtidos a partir da interpretação dos mesmos. O propósito dessa interpretação é o surgimento dos temas significativos que foram derivados das falas dos participantes entrevistados (Thomas, 2006; Vaismoradi, Turunen, Bondas, 2013) e que reportam as experiências, significados e a realidade vivenciada pelos participantes (Braun e Clarke, 2006; Sandelowski e Leeman, 2012).

$\mathrm{Na}$ análise temática o desenvolvimento dos códigos e, posteriormente, dos temas pode ser realizado por meio de dois modos, indutivo ou dedutivo. $\mathrm{Na}$ análise indutiva os temas emergem de um processo de codificação dos dados, sem relação com um quadro de codificação preexistente ou com interesses teóricos do pesquisador no tópico estudado, sendo uma análise orientada apenas pelos dados provenientes da entrevista. Em contrapartida, a análise dedutiva ou temática teórica tende a ser conduzida pelo interesse analítico e teórico do pesquisador na área, o que pode fornecer menos riquezas dos dados em geral (Thorne et al., 1997; Boyatzis, 1998).

Frente ao exposto, no presente estudo optou-se pela análise temática indutiva (Boyatzis, 1998), uma vez que se recorreram aos relatos de experiências, significados e realidade dos participantes perante o fenômeno estudado. Este método de análise permitiu a identificação e descrição dos padrões presentes nos dados, que serão descritos a seguir no item 3.3.4, a Análise e interpretação dos dados. 


\subsection{DESENHO DO ESTUDO}

\subsubsection{Local para realização do estudo}

O estudo foi realizado no Pronto-Socorro Infantil (PSI) de um Hospital de Ensino localizado na zona oeste da cidade de São Paulo e que atende, prioritariamente, moradores da região do Distrito de Saúde do Butantã. Trata-se de uma instituição pública de média complexidade, cuja missão é desenvolver atividades de ensino, pesquisa e assistência hospitalar de nível secundário.

Atualmente, esta instituição apresenta um total de 178 leitos, sendo 12 no $\mathrm{PSI}$, número este que pode variar conforme a demanda de atendimentos, podendo ser instalados leitos extras e/ou isolamentos. O PSI é responsável pelo atendimento de crianças desde seu nascimento até os 14 anos de idade em situações de urgência e emergência. A visão desta instituição e valores estão relacionados a ampliar o desenvolvimento de atividades que sirvam de modelo para outros serviços, assim como integrar todo o processo de atendimento de saúde, com ênfase nos recursos humanos do hospital.

A equipe de enfermagem no PSI é composta por enfermeiros e técnicos de enfermagem que rodiziam entre os plantões diurno e noturno e a equipe médica é composta por pediatras. Há equipe de especialidades de apoio como psiquiatra, por exemplo, porém atendem somente pacientes internados ou em acompanhamento ambulatorial.

Desde dezembro de 2017 o PSI encontra-se referenciado, ou seja, recebe pacientes de outros serviços de saúde da região do Butantã como AMAs (Assistência Médica Ambulatorial) e Prontos-Socorros da região do Butantã. Entretanto, mantém seu pleno atendimento a demandas espontâneas em casos emergenciais, cirúrgicos e ortopédicos.

Em geral, quando o paciente atendido por tentativa de suicídio não tem prévio acompanhamento psiquiátrico é solicitada avaliação externa para um serviço de retaguarda psiquiátrica de emergência e internação na região. 


\subsubsection{Participantes}

Os participantes do estudo foram profissionais de saúde do pronto-socorro infantil que primeiro atendem aos pacientes nos serviços de urgência e emergência, dentre os quais médicos, enfermeiros, técnicos de enfermagem e assistentes sociais.

Para os critérios de inclusão, foram considerados os profissionais atuantes no PSI e que tivessem vivenciado pelo menos uma experiência de atendimento de crianças e adolescentes em tentativa de suicídio.

Como critérios de exclusão foram considerados os profissionais que não tivessem experienciado atendimento de crianças e adolescentes em tentativa de suicídio e os ausentes por motivos de licença saúde ou férias.

O objetivo de uma pesquisa que utiliza a Análise Temática dos dados é selecionar participantes que possam contribuir melhor para a evolução do estudo. Os temas foram gerados por um processo indutivo, em que os códigos emergiram dos dados e foram elaborados conforme o estudo avançou. Portanto, a amostragem não é estatística, e sim teórica, já que o número de participantes não é previamente determinado neste tipo de abordagem (Polit e Beck, 2011).

\subsubsection{Procedimento para coleta dos dados}

A estratégia adotada para a coleta de dados foi a entrevista semiestruturada, considerada importante para a compreensão do significado da experiência.

A entrevista semiestruturada tem como característica questionamentos básicos que são apoiados em teorias e hipóteses que se relacionam ao tema da pesquisa. É utilizada quando os pesquisadores não possuem uma visão preconcebida do conteúdo ou do fluxo das informações a serem reunidas. Seu objetivo é elucidar as percepções dos respondentes em relação ao mundo sem impor as visões dos pesquisadores, que começam o questionamento com uma questão ampla. As questões subsequentes são orientadas pelas respostas iniciais (Polit e Beck, 2011). 
Alguns autores afirmam que a entrevista semiestruturada requer saber escutar, com respeito e curiosidade sobre o que está sendo dito e um esforço sistemático sobre o que as pessoas realmente estão falando. $O$ entrevistador deve apreender a reconhecer e explorar palavras que tenham conotações e significados simbólicos aqueles que estão sendo estudados (Rubin e Rubin, 2012).

Inicialmente, a pesquisadora entrou em contato telefônico e por correio eletrônico com as coordenações de enfermagem e chefias médicas do PSI para apresentar o projeto de pesquisa e solicitar autorização para coleta de dados. A pesquisadora comprometeu-se a começar a coleta, somente após a aprovação do projeto pelos Comitês Ética em Pesquisa da Escola de Enfermagem da Universidade de São Paulo e da Instituição coparticipante deste estudo.

Após a aprovação da realização do estudo pelos Comitês de Éticas, os profissionais foram convidados a participar do estudo, as entrevistas foram agendadas e realizadas pela pesquisadora com os profissionais entre os meses de outubro de 2018 e setembro de 2019, conforme detalhado no Quadro 1 abaixo.

Quadro 1 - Descrição do procedimento de coleta de dados.

\begin{tabular}{|c|c|c|c|c|c|c|c|c|}
\hline \multirow{2}{*}{$\begin{array}{l}\text { Procedimento de coleta dos dados } \\
\text { por trimestre entre os anos de } \\
2018 \text { e } 2019\end{array}$} & \multicolumn{4}{|c|}{2018} & \multicolumn{4}{|c|}{2019} \\
\hline & $1^{\circ}$ trim & $2^{\circ}$ trim & $3^{\circ}$ trim & $4^{\circ}$ trim & $1^{1}$ trim & $2^{\circ}$ trim & $3^{\circ}$ trim & $4^{\circ}$ trim \\
\hline $\begin{array}{l}\text { Apresentação do projeto de pesquisa } \\
\text { às coordenações }\end{array}$ & $x$ & & & & & & & \\
\hline $\begin{array}{l}\text { Aprovação do projeto de pesquisa } \\
\text { pelos Comitês de Ética }\end{array}$ & & $\mathrm{x}$ & & & & & & \\
\hline Entrevistas & & & $\mathrm{x}$ & $\mathrm{x}$ & $\mathrm{x}$ & $\mathrm{x}$ & $\mathrm{x}$ & $\mathrm{x}$ \\
\hline Análise dos dados & & & $\mathrm{x}$ & $\mathrm{x}$ & $\mathrm{x}$ & $\mathrm{x}$ & $\mathrm{x}$ & $\mathrm{x}$ \\
\hline
\end{tabular}


A coleta de dados gerou, aproximadamente, sete horas de entrevistas, sendo a de menor duração com 17 minutos e mais extensa com 45 minutos. As entrevistas foram realizadas nos próprios locais de trabalho dos participantes e tiveram como foco de atenção a compreensão da experiência dos profissionais frente à tentativa de suicídio em crianças e adolescentes. Ressalta-se que, antes de iniciar a entrevista, a pesquisadora explicava o estudo e seus objetivos, bem como os aspectos éticos da pesquisa, dentre eles o Termo de Consentimento Livre e Esclarecido (Apêndice 1), que era lido aos participantes e somente após a assinatura desse a entrevista era iniciada.

As entrevistas foram gravadas e transcritas na íntegra pela pesquisadora, sendo retirados os excessos e os vícios de linguagem, para que houvesse a fluência do texto. As entrevistas tiveram as seguintes questões norteadoras:

"Conte-me uma experiência que você tenha vivenciado com crianças e/ou adolescentes em tentativa de suicídio"

"Como é para você atender uma criança e/ou adolescente em tentativa de suicídio?"

\subsubsection{Análise e interpretação dos dados}

O processo de análise foi guiado pelo referencial metodológico escolhido para este estudo, a Análise Temática. A análise dos dados foi simultânea à coleta de dados e teve início com a codificação aberta onde, a partir de uma leitura exaustiva das entrevistas, foram formados códigos iniciais de informação. Ou seja, as entrevistas dos profissionais foram desmembradas em pequenas frases, examinadas e comparadas quanto às semelhanças e significados.

Por meio da codificação dos dados, a partir dos códigos, foram identificados temas passíveis de descrever e explicar o fenômeno estudado. Segundo Boyatzis (1998), um bom código é aquele que captura a riqueza qualitativa de um fenômeno. Ao codificar as informações, organizamos os dados para, a partir deles, identificar e desenvolver os temas. Boyatzis (1998) definiu um tema como "um padrão na informação que, no mínimo, descreve e organiza as possíveis observações e, no 
máximo, interpreta aspectos de um fenômeno". Além da codificação dos dados, outro fator importante na análise temática é a interpretação dos dados que, segundo Sandelowski e Leeman (2012), envolve criar algo novo proveniente dos dados.

Nesse contexto, a análise temática deste estudo seguiu seis fases, descritas no Diagrama 2 abaixo e organizou os dados em quatro Temas. 
Diagrama 2 - Fases da Análise Temática dos Dados.

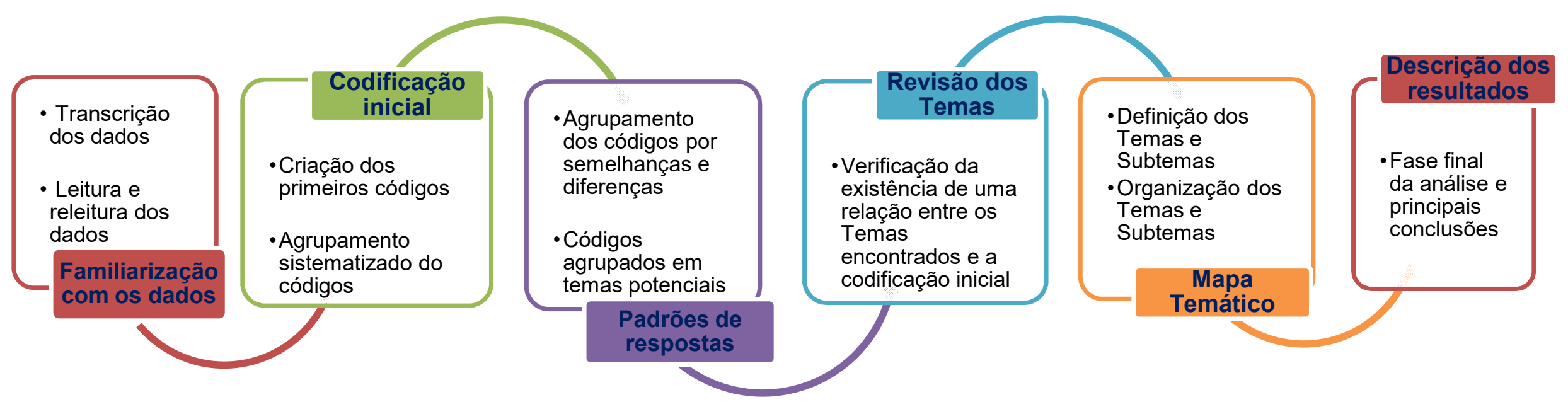




\subsection{ASPECTOS ÉTICOS}

O presente estudo fundamentou-se na Resolução 466, de 12 de Dezembro de 2012 (Brasil, 2012), que regulamenta a pesquisa envolvendo seres humanos, conforme determinação do Conselho Nacional de Saúde, do Ministério da Saúde. Segundo o documento, as obrigações do pesquisador são: garantir o anonimato, a privacidade e a desistência do participante em qualquer etapa do estudo. Esta resolução incorpora princípios da bioética, tais como autonomia, não maleficência, beneficência, justiça e equidade, visando a assegurar os direitos e deveres dos participantes da pesquisa, do pesquisador e do Estado.

Ainda de acordo com a resolução 466/12, o pesquisador deve elaborar o Termo de Consentimento Livre e Esclarecido (TCLE) (Apêndice 1) utilizando linguagem clara, objetiva e de fácil entendimento, garantindo-lhes explicações sobre a natureza da pesquisa, objetivos, métodos, duração da entrevista, benefícios previstos, potenciais riscos, incômodos que esta puder acarretar-lhes, anonimato, autonomia para participar ou não da pesquisa e retirada de participação em qualquer fase do estudo.

Diante da exposição acima este estudo foi encaminhado aos Comitês de Ética em Pesquisa da Escola de Enfermagem da Universidade de São Paulo (Anexo 1) e da Instituição coparticipante (Anexo 2), tendo sido aprovado com pareceres $n^{\circ}$ 2.712.870 e $n^{\circ} 2.778 .446$, respectivamente. 
RESULTADOS 


\section{RESULTADOS}

\subsection{CONTEXTUALIZAÇÃO DOS PARTICIPANTES}

Para o estudo foram selecionados treze profissionais atuantes no prontosocorro infantil, dentre os quais cinco eram enfermeiros, três técnicos de enfermagem, três médicos e dois assistentes sociais. A maioria dos participantes são mulheres (11) e 02 homens, conforme pode ser visualizado no Gráfico 1. Com relação à faixa etária, o Gráfico 2 traz a distribuição dos participantes do estudo em frequência absoluta: entre 26 e 30 anos, 01 participante; 31 a 35 anos, 01; 36 a 40, 05; 41 a 45 anos, $01 ; 51$ a 55 anos, 02; 56 a 60 anos, 02; e entre 61 anos ou mais, 01 participante.

Gráfico 1 - Distribuição dos participantes, segundo o sexo. São Paulo, 2020.

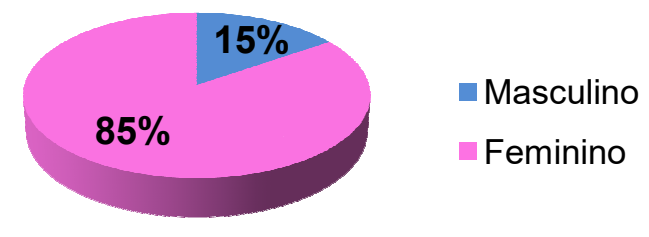

Gráfico 2 - Distribuição dos participantes, segundo a faixa etária. São Paulo, 2020.

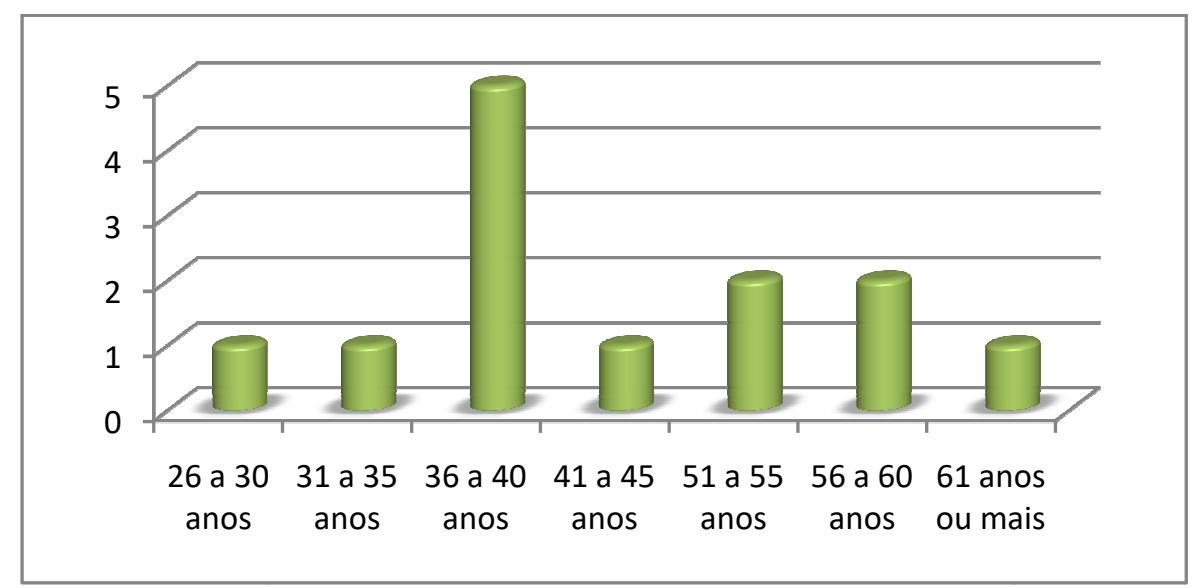


Com relação à maternidade e paternidade, dos 13 participantes, oito (8) têm filhos. Levando-se em conta a religião, seis (6) participantes afirmaram ser católicos; quatro (4), cristãos; um (1), adventista do sétimo dia; um (1), evangélico e um (1), sem religião.

Em referência ao tempo de graduado na respectiva profissão, o Gráfico 3 revela a distribuição em frequência relativa dos profissionais. Ao passo que, o Gráfico 4 mostra a distribuição em frequência relativa do tempo de atuação dos profissionais no PSI. Com relação às capacitações, nove (9) profissionais afirmaram ter realizado cursos de pós-graduação Lato Sensu e cinco (5) Stricto Sensu.

Gráfico 3 - Distribuição dos participantes, segundo o tempo de graduado na profissão. São Paulo, 2020.

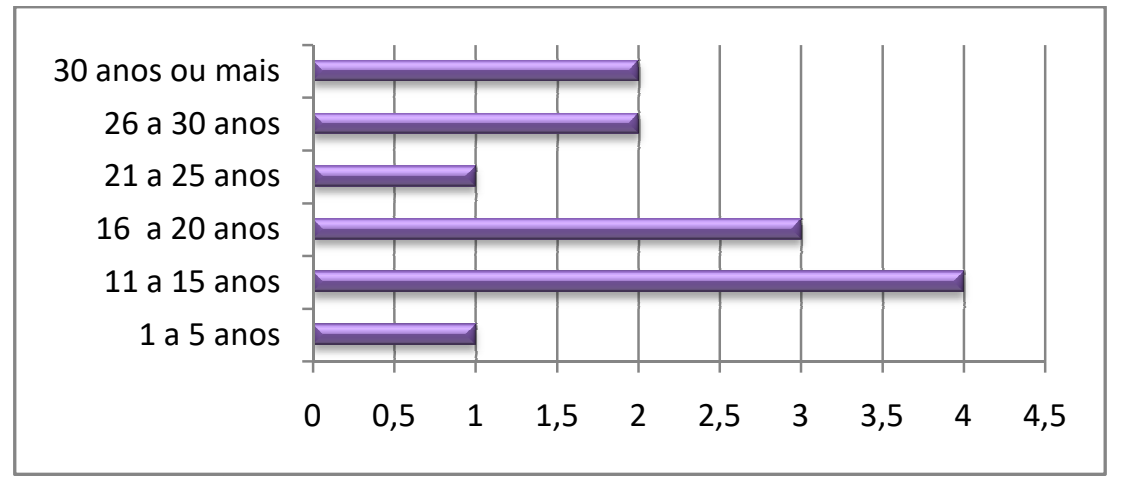

Gráfico 4 - Distribuição dos participantes, segundo o tempo de atuação no prontosocorro infantil. São Paulo, 2020.

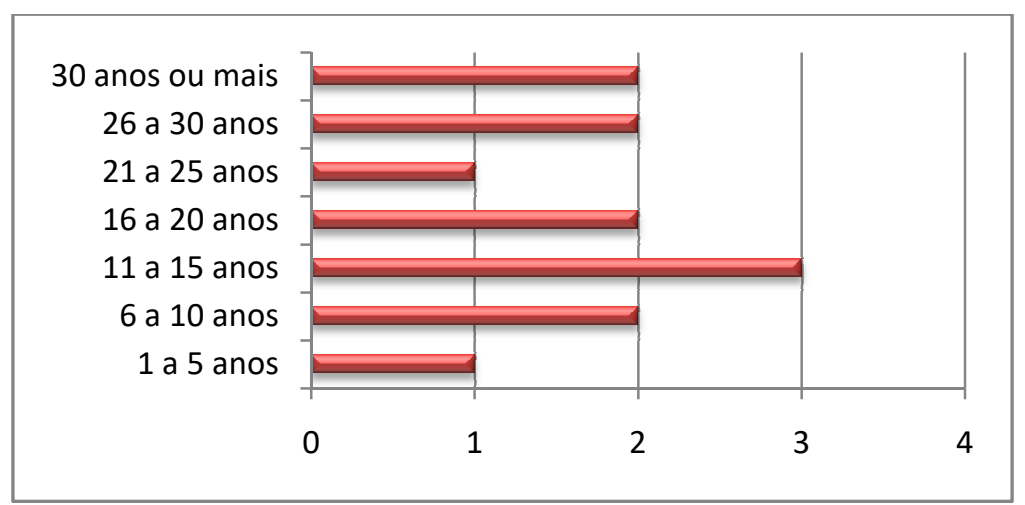




\subsection{A EXPERIÊNCIA DO PROFISSIONAL DE SAÚDE FRENTE À TENTATIVA DE SUICÍDIO EM CRIANÇAS E ADOLESCENTES}

Com o objetivo de compreender a experiência do profissional frente à tentativa de suicídio em crianças e adolescentes as entrevistas foram norteadas por perguntas com foco nesse contexto, conforme mencionado no capítulo anterior do percurso metodológico. Os resultados obtidos na análise das entrevistas foram organizados em quatro (04) temas e onze (11) subtemas, conforme serão apresentados no Mapa Temático a seguir.

A análise das entrevistas permitiu a codificação dos dados e posterior agrupamento por similaridades do conteúdo dos códigos. A experiência foi pontuada desde $\mathrm{o}$ atendimento prestado para salvar a vida da criança e do adolescente que chega ao PSI por tentativa de suicídio até o significado que vivenciar esta situação representa para o profissional que acolhe a criança/adolescente e sua família.

Neste capítulo serão apresentados por meio das falas dos participantes os temas e subtemas que emergiram dos dados. Para manter o anonimato dos participantes, os mesmos foram identificados como: Profissional $(P)$ seguido de uma numeração, por exemplo, Profissional 1 (P1). 
Mapa Temático representativo da experiência do profissional da saúde frente à tentativa de suicídio e crianças e adolescentes.

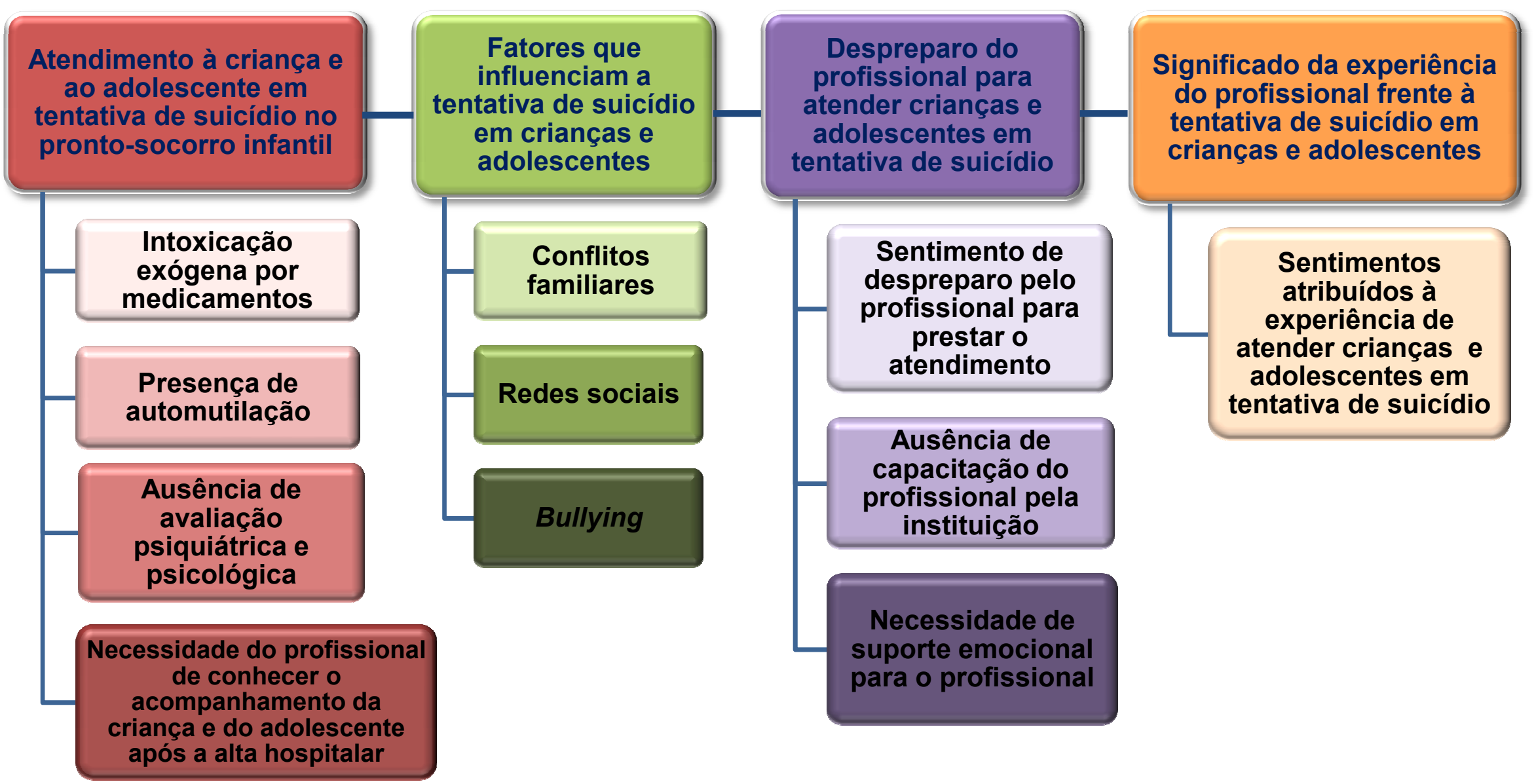


TEMA 1: Atendimento à criança e ao adolescente em tentativa de suicídio no prontosocorro infantil

Os profissionais contam sua experiência a partir das situações por eles vivenciadas durante o atendimento à criança e ao adolescente em tentativa de suicídio no pronto-socorro infantil. Este tema abrange as observações do profissional quando a criança/adolescente em tentativa de suicídio chega ao PSI e as necessidades colocadas pelo profissional após a estabilização hemodinâmica da criança/adolescente, a exemplo do tipo de método utilizado para tentar o suicídio, o achado de autoagressão durante a realização do exame físico, um parecer da psiquiatria e o conhecimento do seguimento no tratamento da criança/adolescente.

A análise dos relatos dos participantes permitiu que quatro subtemas fossem identificados como os pontos mais frequentemente percebidos pelos profissionais ao receber uma criança e/ou adolescente em tentativa de suicídio no pronto-socorro infantil, conforme o Diagrama 3: Intoxicação exógena por medicamentos; Presença da automutilação no exame físico; Ausência da avaliação psiquiátrica e psicológica; Necessidade do profissional de conhecer o acompanhamento da criança e do adolescente após a alta hospitalar.

Diagrama 3 - Atendimento à criança e ao adolescente em tentativa de suicídio no pronto-socorro infantil.

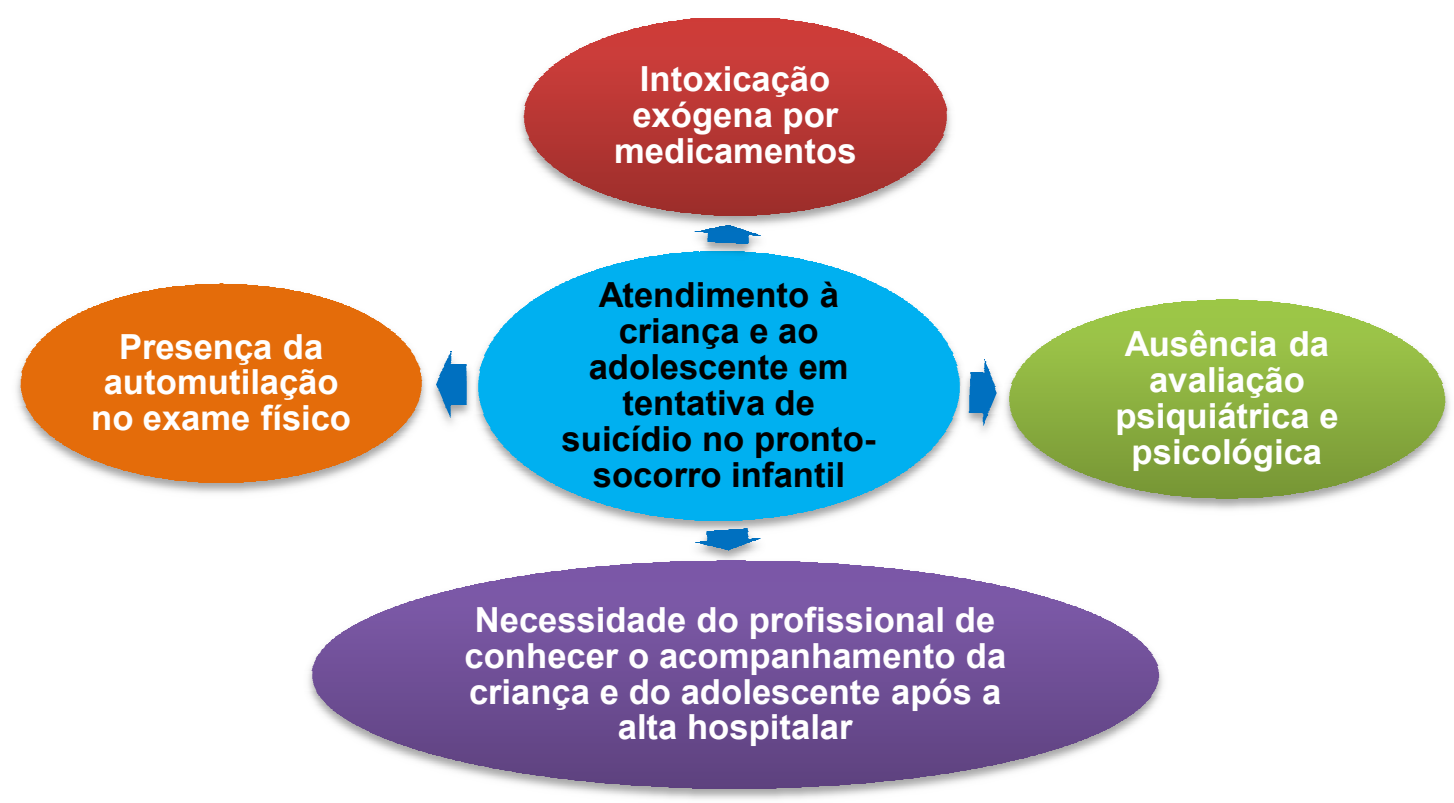




\section{Intoxicação exógena por medicamentos}

As experiências relatadas pelos profissionais são ricas em detalhes com relação aos métodos utilizados pelas crianças e adolescentes na tentativa de suicídio, sendo a Intoxicação exógena por medicamentos a mais frequente nos discursos.

Nesse contexto, os participantes colocaram que as crianças/adolescentes que fazem uso deste meio para tentar o suicídio conseguem acesso aos medicamentos dentro da própria residência, sendo que, em muitos casos, trata-se de medicações de uso controlado para tratamento de transtornos psiquiátricos como a depressão. Ao realizar a anamnese, o profissional verifica que a medicação acessada pela criança/adolescente é utilizada por algum membro da família e, por vezes, utilizada também pela própria criança/adolescente em algum momento anterior.

"Acho que tiveram algumas [experiências], mas uma que nem faz tanto tempo que me marcou pela diferença, era uma adolescente sei lá devia ter uns treze anos, que ela tomou alguns remédios, não lembro bem qual, que algum familiar fazia uso, remédio tarjado, que deu bastante sonolência nela." P1

"Eu vou falar uma [experiência] que aconteceu mais recentemente e que ainda é motivo de discussão entre a equipe. É uma adolescente que mora com a mãe, a avó e as irmãs e ela tentou o suicídio tomando medicações da mãe."P4

"Ela [a mãe] estava muito desesperada, muito preocupada, chorava muito e contou que ele [o adolescente] estava com um quadro depressivo e que tinha tomado toda a cartela dos medicamentos que ele já fazia uso." P13 
Ainda acerca da intoxicação exógena, alguns profissionais pontuaram que a acessibilidade das crianças e dos adolescentes a medicamentos, bem como bebidas alcoólicas e drogas pode estar facilitando a tentativa de suicídio no público infanto juvenil.

“Eu acho o acesso fácil às coisas, entendeu. Porque os jovens, eles estão começando a beber, a usar drogas muito cedo. A beber principalmente, muito cedo. Então, sai para baladas, bebe. Não existe mais criança.” P10.

"Antes a gente via acontecer de outras formas, hoje se usa muito medicamento para tentar suicídio, então assim é um acesso muito facilitado a tudo, eles têm tudo nas mãos, se eles querem usar bebida e misturar com remédio eles conseguem, se eles quiserem tomar veneno também eles conseguem, o acesso é muito aberto, muito fácil pra tudo isso." P4

\section{Presença da automutilação no exame físico}

Quando a criança e o adolescente são levados ao pronto-socorro infantil por tentativa de suicídio, em um primeiro momento busca-se a estabilização hemodinâmica deles. Após o cumprimento dos procedimentos necessários para salvar a vida do paciente, o profissional realiza a anamnese e o exame físico pontuando os achados relevantes, dentre eles a observação de sinais de automutilação.

“Era uma menina também que tinha automutilação. Então quando a gente foi verificar, aliás, é uma coisa frequente que a gente tem visto, não vem na história, mas quando a gente busca de fazer o exame físico, a gente já tem tido esse olhar de olhar os braços, pernas e buscar a automutilação.” P1 
“(..) ela chegou aqui, fez lavagem, esse tipo de procedimento, mas ela tinha situações anteriores, de autoagressão, automutilação, corte, machucaduras assim." P5

Os profissionais estão tendo o cuidado de observar com atenção a presença de automutilação pela criança/adolescente e, em muitos casos, eles associaram a autoagressão com a incidência da tentativa de suicídio e com a presença de um transtorno psiquiátrico, como a depressão.

"Então tinha essa moça [a adolescente], era a segunda tentativa, a outra tinha sido no ano anterior ela tinha ingerido múltiplos medicamentos e chegou aqui fez lavagem, esse tipo de procedimento, mas ela tinha situações anteriores, de autoagressão, automutilação, corte, machucaduras assim." P5

"É difícil, porque quando você vai ver a criança está se cortando toda por causa desses jogos, se automutila, se corta. Isso é porque ela está fragilizada. Ela tenta porque ela está fragilizada." P6

"E, eu não sei, tem isso da criança se cortar e eu vejo muita depressão nessas crianças. Muita depressão. É incrível como você vê as pessoas deprimidas, como têm casos e casos de depressão agora nas crianças. Acho que dez famílias que vem pra cá por isso [pela tentativa de suicídio], nove têm."P10 


\section{Ausência da avaliação psiquiátrica e psicológica}

A fala dos profissionais é unânime ao pontuar que o pronto-socorro infantil precisa de uma avaliação psiquiátrica e psicológica acessível para atender os casos de tentativa de suicídio. A instituição não apresenta em seu quadro de profissionais um psicólogo, ao passo que os médicos psiquiatras atendem em nível ambulatorial e quando acionados pelos setores para prestarem uma interconsulta, dentre eles o pronto-socorro infantil.

Além de questionarem a disponibilidade dos setores de psiquiatria e a ausência de psicólogos, os participantes colocam que a necessidade ideal é a existência de psicólogos e psiquiatras especialistas na área infanto juvenil, para que o atendimento seja centrado na criança/adolescente e sua família.

“A gente tem muita dificuldade essa questão de psicólogo, psiquiatra, não tem na instituição, tem psiquiatra que não é infantil específico que faz uma interconsulta." P1

"Não tem mais nenhuma outra abordagem. Ninguém fala assim "E aí, vocês querem alguma orientação de psiquiatra?", não. Não tem psiquiatra aqui." P11

"Aqui, raramente, você consegue uma avaliação da psiquiatra aqui nesse serviço. São quatro psiquiatras apenas, no hospital, e eles atendem só ambulatório, eles não atendem demanda de Pronto Socorro." P13

Em virtude do contexto exposto acima, o atendimento psiquiátrico é referenciado a um pronto-socorro próximo à instituição e especializado em atendimentos que envolvem a saúde mental. Porém, após a transferência para o serviço referenciado, os profissionais do pronto-socorro não conseguem acesso ao 
seguimento do tratamento da criança e adolescente, o que nos leva ao próximo subtema.

\section{Necessidade do profissional de conhecer o acompanhamento da criança e do} adolescente após a alta hospitalar

Conforme explicitado ao fim do subtema anterior, os profissionais revelaram se sentir angustiados por não conseguirem acompanhar o tratamento da criança e/ou adolescente após a alta hospitalar. Não ter acesso ao seguimento conferido a cada caso de criança e/ou adolescente que tentou o suicídio angustia o profissional e o faz pontuar a necessidade de um psiquiatra e psicólogo na equipe multiprofissional do pronto-socorro infantil, como foi abordado no subitem anterior.

Muitos participantes colocaram que gostariam de manter o contato com a criança/adolescente e sua família para saber se eles estão seguindo o tratamento para que não ocorra uma nova tentativa de suicídio.

"Então depois pra retornar pra rede a gente ver que não tem suporte, eu fico preocupada se vai devolver o adolescente e muitas vezes o adolescente relata que quer tentar de novo e também quando é criança que quer tentar de novo e a família não tem recurso, a família não tem a mínima condição de se pagar uma terapia. E a gente não sabe como ficou esse tratamento." P1

"Agora o aprofundar a gente não consegue fazer isso, não é que eu sinto falta porque o atendimento em si é feito, sinto falta desse acompanhamento mais aprofundado e isso tem, ou vai para um acompanhamento do serviço social ou para o psicólogo, mas não é no pronto socorro, vai de alta e a gente não tem como saber o seguimento desse caso." P2 
"Então não tem, tem vezes que interna tem vezes que não interna, tem vezes que vai de alta e aí você não sabe se aquele caso fica um pouco solto e se perde, se aquela família realmente está fazendo um acompanhamento. Então isso também me angustia e causa angústia na equipe também."P3

"A gente perde o seguimento. Trabalhando no pronto socorro, eu não tenho esse seguimento." P7

"Você perde isso. No pronto socorro, você perde isso. Você não tem um feedback da situação, você não tem a volta do que foi feito. "Ah, tá seguindo agora. Melhorou"."P11

\section{TEMA 2: Fatores que influenciam a tentativa de suicídio em crianças e adolescentes}

Durante a explanação do profissional acerca da experiência em atender crianças e adolescentes em tentativa de suicídio, os participantes levantaram a discussão de que, atualmente, o número de atendimentos de tentativas de suicídio no pronto-socorro infantil está aumentando, bem como identificaram os possíveis fatores que, na opinião deles, podem estar influenciando crianças e adolescentes a tentarem o suicídio (Tema 2).

"Assim, esse em si [a tentativa de suicídio] acho que não tem muitos anos, eu tenho bastante tempo de pronto socorro, é uma coisa recente a coisa das tentativas de suicídio não consigo falar, mas tem alguns anos que percebo que está chegando mais [no pronto-socorro] (...) infelizmente é uma coisa que já faz parte do dia a dia, de lidar com essas situações, com crianças e adolescentes em tentativa de suicídio." P1 
"É uma coisa [a tentativa de suicídio] que a gente tem visto que era uma situação que a gente não via muito na pediatria. $E$ a gente não via. $A$ gente via um caso por ano, sabe assim. Era uma coisa rara que agora tem muito mais." P7

O tema "Fatores que influenciam a tentativa de suicídio pelas crianças e adolescentes" é composto pelos subtemas: Conflitos Familiares; Redes Sociais e Bullying, conforme Diagrama 4 abaixo.

Diagrama 4 - Fatores que influenciam a tentativa de suicídio pelas crianças e adolescentes.

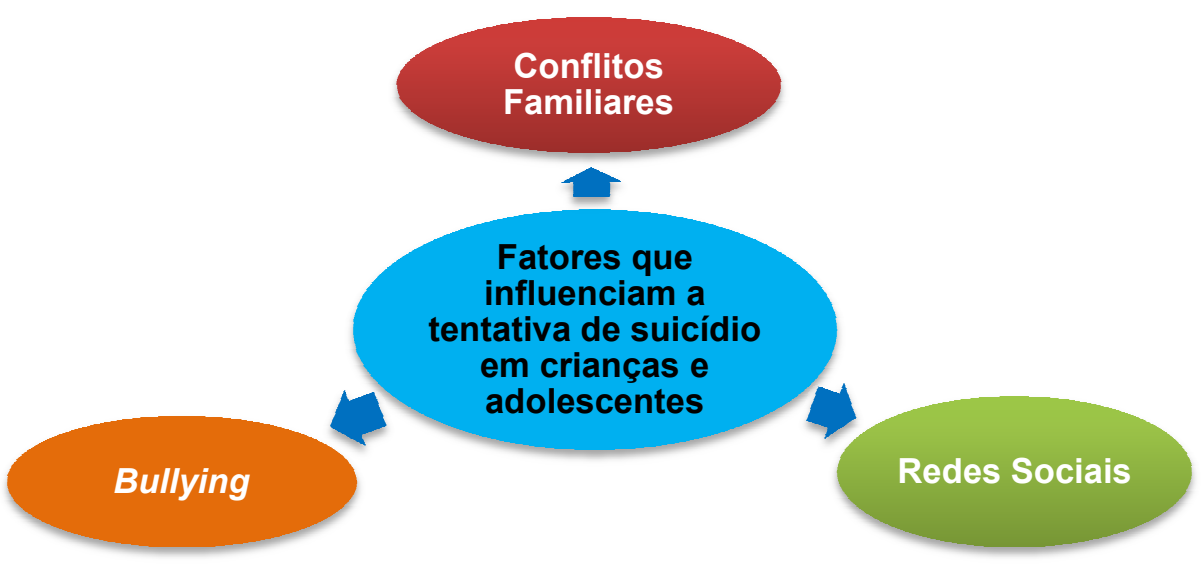

\section{Conflitos familiares}

Dentre os fatores pontuados como influenciadores para a tentativa de suicídio em crianças e adolescentes, Conflitos familiares se destacou pela presença nas falas dos participantes. Além de perceberem que muitas das crianças e adolescentes que chegavam ao pronto-socorro infantil em tentativa de suicídio não apresentavam uma dinâmica familiar satisfatória, os profissionais se mostraram empáticos com a situação do enfrentamento familiar diante do fenômeno da tentativa de suicídio, principalmente os que tinham filhos. 
"Eu vejo que eu tenho um filho, então eu tenho muita preocupação em suprir essa parte emocional de amor de atenção conversando (...) eu percebendo bem menininhos da idade dele e aí é falando de mim, que a mãe supre a falta dando joguinhos de computador pra ele ficar assistindo." P2

"Eu acho que assim, as famílias, a impressão que eu tenho. A estrutura familiar anda muito comprometida. O que você vê são crianças que ficam, eventualmente, isoladas, sozinhas." P11

"Eu acredito que exista o distanciamento das famílias em relação aos filhos, que são pessoas solitárias dentro da própria casa. Então, eu acho que está faltando muito essa aproximação dos pais com os filhos, de estarem atentos ao que eles estão fazendo, ao que eles estão assistindo, o quê que eles estão conversando (...) Me sinto empática, assim, com a família, porque poderia ser eu ali, porque eu também tenho os meus filhos." P13

Nesse contexto de empatia para com as famílias, percebe-se a preocupação dos participantes com o julgamento que a equipe pode transferir para a criança/adolescente que tenta o suicídio e também o impacto que uma base familiar não sólida pode agregar ao desenvolvimento emocional da criança e do adolescente.

"É difícil porque envolve julgamento. Que você não faça no cunho profissional quando você sai daqui e vai para o seu cunho pessoal você carrega julgamentos e acredita, acho porque toda mãe, todo pai, toda família acredita que está fazendo o melhor, e está fazendo o melhor. Mas a gente carrega julgamentos do porquê ele [o adolescente] tentou." P1 
"O que a gente mais vê aqui no hospital são casos que a falta de apoio e suporte familiar é, às vezes os conflitos internos no seio familiar acabam provocando essa atitude no adolescente e mesmo na criança." P4

"Então é difícil dizer que você não pensa no motivo e tal. As pessoas julgam quando sabe, eu já fui assim, hoje em dia eu tento abordar melhor e pensar só no sofrimento que ela [a criança] deve estar passando, sabe. Eu penso que aquela mãe deve estar se sentindo culpada." P6

"Eu acho que, nos dias atuais, a primeira coisa é a família. Essa falta de família, porque não existe hoje pai e mãe. É muito difícil. E quando tem o pai e a mãe juntos, separa e a primeira coisa, a criança perde o chão.” P8

"A base familiar é muito importante, e está se perdendo muito hoje em dia. Pelo o que eu vejo, está se perdendo demais. Então, as crianças não têm uma base familiar." P10

\section{$\underline{\text { Redes Sociais }}$}

Para os profissionais outro fator que, atualmente, influencia a tentativa de suicídio na infância e adolescência são as redes sociais. Para eles, as crianças e os adolescentes integram sua vida real à virtual, sendo que, em muitos casos, os participantes afirmaram que as crianças/adolescentes vivem mais em função da vida perfeita projetada na tela dos eletrônicos. Esse contexto pode tornar a criança e o adolescente introvertidos e propensos à tentativa de suicídio. 
"Hoje com a questão das redes sociais, essa questão da tecnologia muito dentro da vida do adolescente e da criança mesmo, isso que há 15 anos não existia. Não existia o wi-fi há dez anos. Hoje em dia a criança e o adolescente estão o tempo todo ligados na tecnologia com pouca interação familiar. Então se busca muito mais, acho que antes se buscasse muito mais nos pais outros recursos e muito mais diálogos em relação aos problemas. Hoje em dia é muito mais com amigos ou com o grupo de apoio, um grupo de facebook e isso tem um lado bom e tem um lado perigoso, um lado ruim, são muitas informações para se lidar." P1

"Então assim, as redes sociais, por exemplo, fazem com que a pessoa vá se individualizando apesar do coletivo, apesar de tudo ter uma visibilidade muito ampla, mas ela vai ficando cada vez mais introspectiva. Então a rede de amigos dela é virtual, então assim se ela tem alguma vergonha ou timidez e tudo ela vai se escondendo atrás disso e com isso ela não conversa muito com os pais, com a família”. P4

Além das redes sociais, alguns participantes pontuaram a internet em sim e a acessibilidade que ela traz como um fator que interfere no comportamento da população pediátrica, no sentido de que 0 acessível pode tornar as crianças/adolescentes mais ligados no mundo on-line do que no real.

“Eu não sei se é a interação dentro de casa, eu não sei se é a falta de comunicação. Eu não sei se é essa era de internet, que eu vejo muito são as pessoas, todo mundo preocupado mais com whatsapp do que com quem está ali." P9 
"Hoje, você tem uma permissividade maior. Hoje, você tem uma internet, um acesso à informação muito maior. Tudo isso, as redes sociais, tudo isso daí, acaba interferindo de um modo ou de outro, no comportamento dessas crianças." P11

\section{Bullying}

Outra questão levantada pelos profissionais em suas falas e que integra a realidade atual acerca da temática deste estudo é o enfrentamento pela criança e adolescente do bullying que, conforme colocado no capítulo da introdução, significa atos de violência física e psicológica, praticados intencionalmente ou não.

Os participantes pontuam em suas experiências a observância da presença da prática do bullying na rotina das crianças e adolescentes, bem como observam uma influência desde fenômeno na prática da tentativa de suicídio.

"Eu acredito que assim, a frequência ela aumenta cada vez mais. Esses adolescentes, eu não sei como acontece nos outros serviços, mas os que a gente vê aqui são adolescentes bastante introspectivos, são pessoas que não têm muitos amigos, alguns porque sofreram bullying na escola." P4

"Eu sofri bullying na escola, mas eu aprendi a me defender. Eu penso que as crianças não são preparadas pela família para se defender. Elas vão sofrer bullying e não vão saber lidar com isso, daí vai ficar depressiva e a depressão vai levar até chegar a cometer o suicídio na infância ou na vida adulta." P6 
"Porque, às vezes, não é só uma tentativa de suicídio; às vezes, é um bullying,é uma sensação, é uma violência psicológica. E eles estão muito mais sensíveis. Eu sinto que os adolescentes, hoje, estão muito mais sensíveis a qualquer afronta. Eles respondem de uma maneira muito, muito, muito introjetada, engolindo." P7

TEMA 3: Despreparo do profissional para atender crianças e adolescentes em tentativa de suicídio

O relato dos profissionais acerca das suas experiências no atendimento aos casos de tentativa de suicídio revela que observaram um aumento no número de casos que chegam ao pronto-socorro infantil por este motivo, conforme pontuado anteriormente. Nesse contexto, outro fator presente nas falas dos participantes é o sentimento de despreparo para atender à criança e ao adolescente em tentativa de suicídio. Aqui não se faz a referência ao atendimento de estabilização do quadro clínico do paciente, mas à abordagem e ao acolhimento da criança/ adolescente e sua família.

O Tema 3 faz referência desde o despreparo do profissional, às ausências de capacitação oferecida pela instituição e de suporte emocional, perfazendo três subtemas: Sentimento de despreparo pelo profissional para prestar o atendimento; Ausência de capacitação do profissional pela instituição; Necessidade de um suporte emocional para o profissional (Diagrama 5). 
Diagrama 5 - Despreparo do profissional para atender crianças e adolescentes em tentativa de suicídio.

\section{Sentimento de despreparo}

pelo profissional para

prestar 0 atendimento

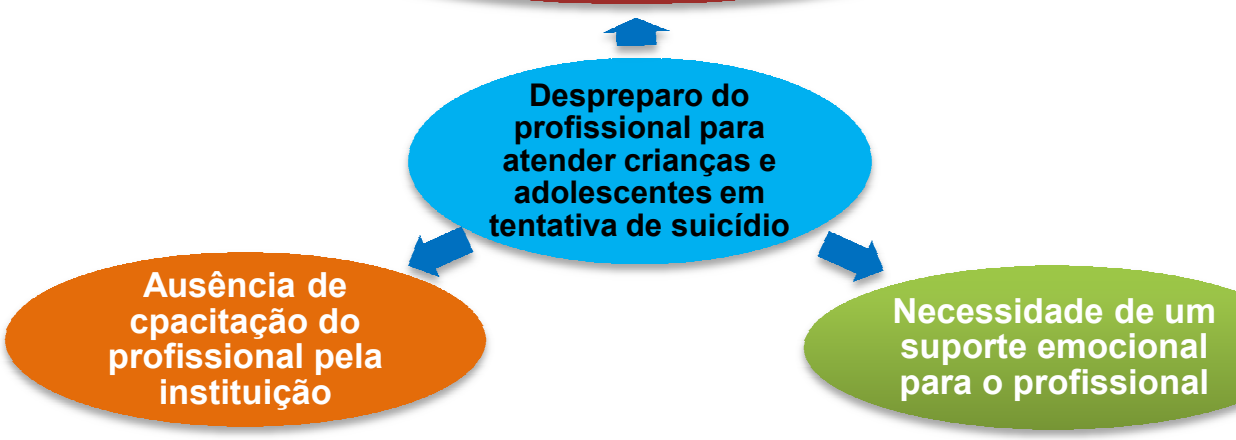

\section{Sentimento de despreparo pelo profissional para prestar o atendimento}

Este subtema revela, nos relatos dos próprios profissionais, que eles não se sentem preparados para prestar o atendimento no pronto-socorro infantil por tentativa de suicídio. Nesse caso, a referência de atendimento é relacionada à abordagem da criança/ adolescente e sua família, pois com relação ao atendimento assistencial de urgência e emergência os participantes indicam a realização primordial, conforme as falas abaixo.

“Logo é feito o procedimento padrão que é padronizado para intoxicações exógenas, lógico que os casos que é passagem de sonda, lavagem gástrica, carvão ativado e todo esse protocolo de atendimento de melhoria da estabilidade hemodinâmica do paciente. Em relação ao psicológico é muito vago. Aqui para gente no pronto socorro é muito vago, a gente não tem essa interação muito aprofundada em relação a isso." P2 
"Então, a gente dar aquilo, claro que no pronto socorro, a gente vai restabelecer as funções vitais. Se tem uma indicação de lavagem gástrica, se tem uma necessidade de punção venosa e expansão, a gente vai correr para fazer primeiro esses procedimentos de ordem de restauração mesmo dos sinais vitais." P13

Com relação à abordagem inicial e ao acolhimento emocional e psicológico da criança/adolescente e sua família, muitos participantes afirmaram não se sentir preparados para realizá-los, seja pela falta deste assunto durante sua formação profissional ou pela dificuldade pessoal de aproximação para com as pessoas que tentam o suicídio.

"Então as perguntas precisam ser direcionadas e as ferramentas de como vou trabalhar com este problema, para onde vou direcionar esse problema. Então fica sempre aquela construção individual, não existe um protocolo, alguma coisa do que fazer nessas situações e vai do achismo, um acha uma coisa o outro acha outra." P1

"Por conta da nossa formação, que não existe um protocolo, algo que norteie o atendimento desses pacientes, seja por parte da equipe médica, de enfermagem. Sempre são casos que ficam muito soltos e isso é uma angústia pelo menos para mim, porque mesmo durante o cuidado, a abordagem eu não sei se está sendo feito de forma correta." P3

"Preparada eu não me sinto. Eu acho que deveria haver esse preparo já quando você começa a trabalhar (...) é um tema que como está aumentando muito, às vezes, a pessoa nem tem isso. Eu não tive na minha faculdade, como tratar uma criança que tentou suicídio, mas daí você vai aprender no dia a dia." P8 
"Eu, sinceramente, não sinto muito preparo, não sei muito bem qual é a abordagem ideal, porque a gente sempre acaba tendo a facilidade "Ah, tem que ter a avaliação do psiquiatra". Então, essa parte, a gente, sinceramente, eu não sinto preparo." P12

\section{Ausência de capacitação do profissional pela instituição}

Ainda no âmbito da abordagem e acolhimento da criança/adolescente e sua família, os participantes pontuaram em suas falas a necessidade de capacitações por parte da instituição, no intuito de deixar o profissional mais preparado para prestar o atendimento à tentativa de suicídio, pois conforme o subitem anterior os profissionais não se sentem preparados para atender uma criança e/ou adolescente em tentativa de suicídio.

Observou-se que muitos profissionais opinaram sobre quais ferramentas a instituição poderia utilizar para oferecer essas habilitações à equipe do prontosocorro infantil.

"Acho que tinha que ter cursos dentro da própria instituição, mas que viesse gente de fora, especialista no assunto que fizesse de forma multiprofissional que aqui no nosso setor seria a parte médica, de enfermagem e assistente social que são os que atuam. (...) A instituição trabalha muito com protocolos. Não estou falando de um protocolo engessado porque ele também tem que ter uma flexibilidade, mas até para o quê quer que vai fazer, pra não se esquecer os passos, o que se deve fazer e algumas perguntas direcionadas para o problema, acho que seriam interessantes. Um protocolo de como você vai abordar a situação, o que você vai fazer, o que não pode deixar de fazer então não sei."P1 
"Então eu não sei, por isso que eu falo eu não sei se é curso, se é um profissional que possa ensinar, se é alguma reciclagem, se é palestra. Eu acho que está faltando sim o quê que eu devo falar, qual o momento, de que forma eu tenho que abordar essa parte psicológica. Porque de repente a gente aborda achando que é o melhor jeito e não é, está piorando a situação." P2

"Preparo a gente não tem. O que poderia fazer era a instituição oferecer cursos, palestras com especialista em suicídio. Porque muita gente não sabe o que perguntar nem o que fazer quando chega os casos de tentativa de suicídio, ninguém sabe." P5

"De como você pode abordar essas crianças, de que tipo de instrumentos você pode ter para tentar conquistar uma certa confiança e obter esse acolhimento, porque eu não tenho esses instrumentos. Eu até tenho, eu sei que tenho, por experiência, mas têm casos que fogem. E, nesses casos que fogem, como é que a gente pode fazer." P7

"Existem aspectos humanos que são endógenos. Eu tenho. Algumas pessoas não têm. E elas raramente vão ter ou vão querer ter (...) não dá para obrigar ninguém a ter aptidões humanas, porque eu acredito muito que isso é um olhar de sensibilidade, de empatia, de disposição a acolher o sofrimento. (...) O manejo do comportamento suicida no pronto socorro, ele é, de fato, algo pessoal. Acaba ficando muito no âmbito pessoal. Acredito que o hospital, por exemplo, poderia identificar pessoas com esses perfis e torná-las referência para esse tipo de acolhimento. Que existisse alguém, um lugar, uma equipe própria para atuar nessas situações, para dar o acolhimento, que esteja capacitada, que esteja apta para fazer esse tipo de acolhimento, porque aí, realmente, não é qualquer pessoa." $\mathrm{P} 13$ 


\section{Necessidade de um suporte emocional para o profissional}

Além do despreparo para prestar o atendimento às crianças e adolescentes em tentativa de suicídio, os profissionais relataram a necessidade de um suporte emocional à equipe que gerencia o cuidado às crianças/adolescentes e suas famílias, pois a temática abordada neste estudo é rodeada de tabus e perspectivas pessoais, onde o profissional deposita suas crenças e valores acerca do assunto, o que pode influenciar na maneira como o profissional irá internalizar essa situação dentro de si.

“Então muitas vezes [o profissional] traz para si a história, comparando com a sua própria vida pessoal e fazendo reflexões sobre suas próprias crenças. (...) Então ter um apoio seria muito importante porque são histórias que acabam marcando, que você eu acho que nem sei se, por exemplo, pra tentativa de suicídio talvez uma terapia em grupo, vamos trabalhar com o grupo que atendeu aquele atendimento, vamos fazer uma discussão em grupo, acho que algumas situações a terapia ou o trabalho com o psicólogo com a equipe em grupo não só trabalha com as angústias que a situação levou, como ajuda a ter suporte maior para as próximas situações que virão. Então acho muito importante, mas a gente não tem." P1

“(...) muitas pessoas também estão em sofrimento e estão trabalhando aqui. A gente não sabe a fundo o que todo mundo tem passado. Mas que uma tentativa de suicídio deixa todo mundo mexido em algum aspecto, sim. Não tem uma pessoa, aqui, hoje, que eu trabalho que se sinta alheio a essa situação. (...) O suporte quem dá é uma dá para outra. A gente conversa muito. Digo conversas informais mesmo. Eu acredito que, se tivesse uma coisa, realmente planejada, para que a gente possa conversar. Uma roda, para gente poder conversar, pra poder falar o quê que eu senti nesse atendimento." P13 
TEMA 4: Significado da experiência do profissional frente à tentativa de suicídio em crianças e adolescentes

O último tema delimitado pela análise das falas dos participantes faz referência ao significado que a experiência em atender uma criança e/ou adolescente em tentativa de suicídio tem para o profissional.

Quando questionados acerca de qual seria o significado desta experiência, os profissionais colocaram em sentimentos o que significava para eles receber uma tentativa de suicídio nessa faixa etária. Frente a isso, o Tema 4 perfaz um subtema: Sentimentos atribuídos à experiência frente à tentativa de suicídio em crianças e adolescentes.

Diagrama 6 - Significado da experiência do profissional frente à tentativa de suicídio em crianças e adolescentes.

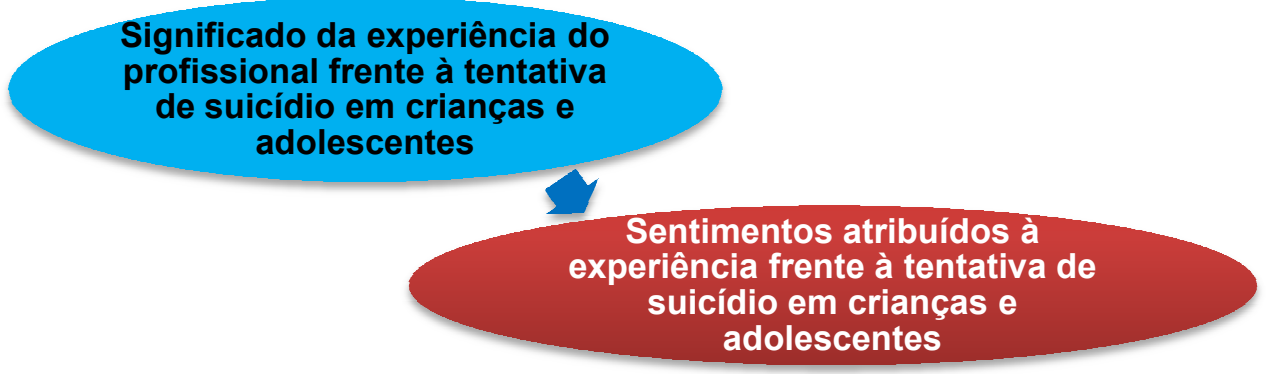

Sentimentos atribuídos à experiência frente à tentativa de suicídio em crianças e adolescentes

Os significados atribuídos pelos profissionais à experiência de receber no pronto-socorro uma criança/adolescente por tentativa de suicídio foram colocados em palavras na forma de sentimentos e sensações, sendo os mais frequentes a frustração, a angústia, a tristeza e a impotência.

O fenômeno da tentativa de suicídio perfaz uma lógica de difícil compreensão, pois para muitos profissionais o público infanto-juvenil representa vida, sendo complexo atender um caso que vai contra esse fato. Muitos participantes não encontraram palavras que os ajudasse a responder o significado que a experiência 
aqui em destaque representa para eles, e destacaram essa experiência como um desafio profissional e pessoal.

"É um desafio, mas também é uma possibilidade. Uma possibilidade de crescimento profissional, de um novo aprendizado embora desafiador". P1

"Vou te falar em uma palavra, para mim é impotência. Para mim sempre fica algo a desejar, então para mim é frustrante, não estou prestando o melhor atendimento." P3

"É frustrante. Assim, não é que é frustrante o atendimento, mas é frustrante você atender uma situação dessas. Quer dizer, porque isso significa que várias coisas falharam para você chegar ali." P7

“É angustiante, (...) uma frustração, entendeu. Não tem como a gente conseguir reverter isso. Se conseguisse reverter esse psicológico, seria bom. (...). É uma tristeza, é se compadecer mesmo pela família, porque por mais que a gente saiba que tem falha, a gente não tem certeza, de quem que é a falha, a gente não pode julgar, não entrar com julgamento; então, dá essa tristeza, essa angústia mesmo." P9

“Então, óbvio, não é o melhor atendimento que você gosta de dar. Porque você gosta de dar o atendimento para pessoas que realmente estão sofrendo, por alguma doença, por alguma coisa, e que procuram você pra sanar isso. Aquele que faz uma tentativa de suicídio, você vai só tomar uma conduta para tirá-lo daquele caos que ele se encontra (...), eu cumpro o meu papel. Só. Oriento, faço o que preciso fazer. Ponto, só isso. Mas não é uma coisa gratificante." P11 


\section{DISCUSSÃO}

Este estudo buscou compreender, sob o ponto de vista dos profissionais de saúde sua experiência frente à tentativa de suicídio em crianças e adolescentes. $A$ partir da análise das narrativas, observou-se que os resultados se aproximaram da concepção do Interacionismo Simbólico, em que as crenças e os valores dos profissionais de saúde conduziram seus comportamentos e decisões no atendimento inicial no pronto-socorro infantil.

Os resultados desta pesquisa contribuem e ampliam o conhecimento sobre a tentativa de suicídio em crianças e adolescentes sob o olhar do profissional de saúde que presta o atendimento inicial no pronto-socorro infantil. Com isso, emergiram quatro temas: Atendimento à criança e ao adolescente em tentativa de suicídio no pronto-socorro infantil; Fatores que influenciam a tentativa de suicídio em crianças e adolescentes; Despreparo do profissional para atender crianças e adolescentes em tentativa de suicídio; e Significado da experiência do profissional frente à tentativa de suicídio em crianças e adolescentes, discutidos sequencialmente.

O Tema 1, "Atendimento à criança e ao adolescente em tentativa de suicídio no pronto-socorro infantil", traz os principais pontos destacados pelos profissionais quando recebem uma criança e/ou adolescente em tentativa de suicídio, sendo a intoxicação exógena por medicamentos o meio mais frequentemente utilizado para tentar o suicídio. Este dado vai de encontro ao levantamento realizado pelo Ministério da Saúde (Brasil, 2017) em relação ao perfil de óbitos por suicídio no Brasil no período de 2011 a 2015, no qual além da intoxicação exógena está o disparo por arma de fogo dentre os meios mais utilizados pelo público infanto-juvenil.

O uso excessivo de medicamentos é recorrente na literatura nacional e internacional dentre os meios mais utilizados para tentar o suicídio (Santos, Coimbra e Ribeiro, 2011; Santos, Legay e Lovisi, 2013; Vieira, Santana e Suchara, 2015; Cluver et al., 2015; Koenig et al., 2017; Lévesque et al., 2017; Vaz-Tostes et al., 2019), o que revela a importância de medidas preventivas para o suicídio como o armazenamento adequado de remédios e o uso controlado desses. 
Ainda durante o atendimento de estabilização das funções vitais das crianças e dos adolescentes que chegam ao pronto-socorro infantil por tentativa de suicídio, os profissionais trouxeram em suas falas que observaram a presença da automutilação ao realizarem o exame físico. Percebe-se que este achado está relacionado ao planejamento do suicídio e número de tentativas realizadas, onde a criança e/ou adolescente confere a si mesmo lesões que podem evoluir à tentativa de tirar a própria a vida (Jans et al., 2017; Brasil, 2019a; Brasil, 2019b).

Nesse contexto, em 2019 foi instituída a Política Nacional de Prevenção da Automutilação e do Suicídio a partir da Lei 13.819 (Brasil, 2019a), na qual em seu Artigo $6^{\circ}$, "os casos suspeitos ou confirmados de violência autoprovocada são de notificação compulsória pelos estabelecimentos de saúde públicos e privados às autoridades sanitárias; e estabelecimentos de ensino públicos e privados ao conselho tutelar."

Segundo Silva (2019), este fluxo de notificação precisa ser integrado para que os dados provenientes das notificações sejam fidedignos o bastante a ponto de auxiliar o planejamento de ações. Porém, é fundamental que haja capacitação adequada dos profissionais, no sentido de viabilizar o acolhimento adequado e o encaminhamento em tempo oportuno para cuidado específico na rede de atenção à saúde (Silva, 2019), o que nos leva ao Tema 3 deste estudo: "Despreparo do profissional para atender crianças e adolescentes em tentativa de suicídio."

Profissionais de saúde que trabalham em serviços de urgência e emergência, geralmente são os primeiros a acolherem pessoas por tentativa de suicídio no sistema de saúde, sendo encarregados de avaliar as necessidades de cada um adequadamente, a fim de prevenir novas tentativas. Mas esse cenário nem sempre é tranquilo, pois alguns profissionais podem interpretar a tentativa de suicídio como uma afronta à vida, o que os fazem agir de maneira negativa frente à pessoa e sua família, comprometendo a assistência a ser prestada. Essa abordagem, por vezes repulsiva e incompreensível, pode piorar o estado da pessoa, diminuindo as chances de procura pelos serviços de saúde (Navarro e Martínez, 2012; Heck et al., 2012).

Para alcançar um cuidado integral e de qualidade, o primeiro passo é oferecer qualificação ao profissional para que este consiga prestar um acolhimento 
individualizado, respeitando a criança e o adolescente, analisando e compreendendo os riscos. Assim, melhores intervenções terapêuticas serão realizadas diminuindo o risco de que a ideação suicida se transforme em uma tentativa e subsequentemente para o ato consumado do suicídio (De Abreu et al., 2010). No entanto, os profissionais não se sentem preparados para prestar o atendimento.

Segundo os participantes deste estudo, a formação profissional não engloba temáticas como a tentativa de suicídio em crianças e adolescentes e a instituição não prover capacitações para os profissionais que atuam na linha de frente para receber o paciente que tenta o suicídio, o que os leva a enfrentar questões emocionais acerca do tema e do atendimento prestado, pois eles não sabem como agir perante o fenômeno do suicídio e com as consequências que este atendimento gera em suas emoções, fato esse evidenciado na literatura (Bertolote et al., 2010; Vannoy et al., 2011; Carmona-Navarro, Pichardo Martínez, 2012; Antai-Otong, 2016).

Uma das questões que, na perspectiva do fenômeno do suicídio em crianças e adolescentes, o profissional precisa estar capacitado para identificar e saber como agir quando da presença deles são os "Fatores que influenciam a tentativa de suicídio em crianças e adolescentes", o Tema 2 deste estudo.

São inúmeros os fatores que predispõem a criança e o adolescente a apresentarem comportamento suicida, sendo a idade e o gênero os mais destacados, visto que, assim como ocorre na população adulta, os meninos se suicidam mais que as meninas. As meninas, por sua vez, apresentam mais tentativas que os meninos e utilizam métodos que não prejudicam tanto a aparência física, fazendo uso, por exemplo, de medicações em excesso ou produtos químicos. Já os meninos, utilizam métodos mais letais, como o uso de armas de fogo e enforcamento, principalmente na adolescência (15-18 anos) (Braga, Dell'Aglio, 2013; Trujillo, Elías, Acosta, 2013; Hauser, Galling, Correll, 2013; Ng et al., 2015).

Outro fator de risco são os problemas de saúde mental, que acometem $90 \%$ das pessoas que se suicidam, englobando os transtornos psíquicos, de personalidade, impulsividade, baixa autoestima, isolamento social e psicopatologias, sendo a depressão o pior agravante. Histórico familiar de suicídio ou tentativa de 
suicídio na família também é um fator de risco considerado relevante (Braga, Dell'Aglio, 2013; Hauser, Galling, Correll, 2013; Fernández, Santana, Sánchez, 2014; Ng et al., 2015).

Há ainda o histórico de abuso físico, verbal ou sexual, orientação sexual e os fatores socioeconômicos que contemplam o ambiente em que vivem (moradores de rua, dependentes de abrigo, orfanato, entre outros). Em relação à condição financeira, alguns estudos evidenciam que quanto mais pobre, maior a probabilidade de vir a ter comportamento suicida (Rasmussen, Martín, 2015; Czyz, King, 2015; Sullivan et al., 2015).

Os conflitos familiares, identificados pelos participantes deste estudo são importantes fatores de risco, já que relações familiares e com os amigos, desde que com vínculos efetivos, são essenciais para o desenvolvimento saudável da criança e adolescente (Braga, Dell'Aglio, 2013; Ferrara et al., 2014). Nesse contexto, outro fator que pode influenciar a tentativa de suicídio pela criança e adolescente e que afeta o desenvolvimento saudável colocado na frase anterior é a prática do bullying.

O bullying, como já mencionado, pode ser definido como um ato agressivo realizado por um grupo ou por um indivíduo, repetidamente e ao longo do tempo, contra uma vítima que não pode facilmente se defender (Araújo et al., 2020). Atualmente, a modalidade de bullying mais frequente na faixa etária infantil e na adolescência é o cyberbullying ou bullying virtual, o que remota a outro fator identificado pelos participantes deste estudo como influenciador para a tentativa de suicídio em crianças e adolescentes, as redes sociais (Feinberg, Robey, 2010; Alves e Ferreira, 2019; Araújo et al., 2020).

Atualmente, em virtude da globalização, o acesso à internet está facilitado e cada vez mais frequente entre as famílias. Crianças são gestadas sob a influência das mídias sociais e os adolescentes mantêm vida dupla, uma real e outra virtual. Estudos mostram a influência que o estímulo precoce e excessivo ao uso da internet pelas crianças e adolescentes pode trazer repercussões até a vida adulta, além de agir diretamente no desenvolvimento cognitivo e na autoestima desta população, a tornando mais vulnerável a fenômenos como o suicídio (Asevedo et al., 2018; JaenVaras et al., 2019) 
Para os participantes deste estudo, a internet está muito dentro da vida das famílias fazendo com que crianças e adolescentes se sintam sozinho na própria casa, a partir disso eles buscam nas redes sociais algo que possa preencher esse vazio. Porém, muitas vezes eles são afetados pela realidade que os outros montam em fotos e vídeos e, então, na tentativa de diminuírem seu sofrimento atentam contra a própria vida.

Nessa perspectiva, o desenvolvimento de ações preventivas atreladas ao conhecimento dos fatores de risco para o suicídio, sobre os quais os profissionais de saúde precisam agir é necessário (Navarro, Martínez, 2012).

A efetividade dessas ações poderá ser avaliada a partir dos três níveis de práticas baseadas em evidências para o comportamento suicida (Heck et al., 2012): nível indicado - adequado para aqueles que têm um alto risco de cometer suicídio, que necessita de intervenções individuais e especializadas; nível seletivo adequado para subgrupos com maior risco de suicídio, como crianças e adolescentes; nível universal - utilizado para toda a população, sem distinções.

Muitos estudos são realizados acerca das ações preventivas e suas intervenções para o nível indicado, enquanto são poucos os estudos relacionados aos níveis seletivo e universal, seja por falta de critérios baseado em evidências ou políticas públicas (Heck et al., 2012; Brasil, 2019a; Brasil, 2019b).

Crianças e adolescentes integram o nível seletivo e com relação a essa população, estima-se que $60 \%$ dela necessitam de apoio à saúde mental, porém não o recebe, o que dificulta a detecção dos riscos de suicídio nessa faixa etária, sendo que este também é o grupo que menos procura ajuda. Por ser um grupo de alto risco ao suicídio e no qual ainda se têm uma menor chance de abordagem para realização das intervenções, é vital a existência de estratégias adequadas para prevenção ao suicídio (Collado et al., 2014; Brasil, 2019a).

No Brasil, o suicídio somente começou a ganhar destaque com a análise das taxas de violência no país, quando foi possível evidenciar que o suicídio era um dos principais atos cometidos. Em 2005, o suicídio já era considerado um problema de saúde pública e, desde então, algumas estratégias visando a prevenção foram publicadas em documentos nacionais oficiais, até que recentemente um deles foi 
divulgado com foco para o suicídio e a automutilação entre crianças, adolescentes e jovens (Brasil, 2019a).

Frente ao exposto e aos resultados deste estudo, percebe-se que o suicídio é um fenômeno de difícil compreensão e para o profissional não é fácil conceber que uma criança e/ou adolescente quer tirar a própria vida, o que desperta sentimentos e significados no profissional. O Tema 4 deste estudo, "Significado da experiência do profissional frente à tentativa de suicídio em crianças e adolescentes" refere-se ao significado que a experiência de atender uma criança e/ou adolescente tem para o profissional de saúde e a forma encontrada pelos participantes de colocar esse significado em palavras foram transformá-lo em sentimentos ou em símbolos, como conceituado pelo Interacionismo Simbólico.

Os sentimentos atribuídos pelos profissionais ao fenômeno da tentativa de suicídio em crianças e adolescentes assim como o Símbolo do Interacionismo Simbólico, servem para que o indivíduo possa nomear o que para ele tem significado, de maneira que assim ele consiga comunicar-se com os outros e consigo (Ação Humana e Self), ou seja, estabelecer uma Interação Social.

Os Temas que emergiram da análise das falas dos participantes permitiram a compreensão do que foi vivenciado a partir dos significados atribuídos e das colocações que os participantes fizeram para si próprio, sendo que nesse processo (Mente) o profissional se percebeu ( $\underline{\text { Self}}$ ) e se colocou no lugar do outro (Assumir o papel do outro).

Vale ressaltar que a literatura sobre suicídio na infância e na adolescência focaliza o comportamento suicida como o ato de auto infligir danos, podendo vir de: pensamentos suicidas (ideação suicida), tentativas de suicídio e o suicídio consumado. Trata-se de casos que ocorrem dentro de um determinado contexto social e que, muitas vezes, demonstram pedidos de ajuda, abrangem diversos mecanismos que não são totalmente explicitados e são vistos como um tabu pela sociedade, acerca da falta de entendimento dessa atitude complexa que pode ser provocada por diversos fatores biopsicossociais (De Abreu et al., 2010; López et al., 2016; Jans et al., 2017; Brasil, 2019a). 
De acordo com o modelo biomédico, o comportamento suicida acontece por meio de transtornos psiquiátricos com causas biológicas, sendo de difícil compreensão o ato em que um indivíduo arquiteta a sua própria morte (Vaz-Tostes et al., 2019).

As estimativas da OMS revelam que a quantidade de tentativas de suicídio ultrapassa a das vítimas que cometem o suicídio, sendo a tentativa o principal fator de risco para a possível concretização do ato (Brasil, 2019a). Nesse contexto, o suicídio é a ponta de um "iceberg", pois é difícil mensurar, com exatidão, quantos casos de fato ocorrem, visto que muitos não são devidamente notificados (Botega, 2013). 


\section{CONSIDERAÇÕES FINAIS}




\section{CONSIDERAÇÕES FINAIS}

Este estudo buscou compreender, na perspectiva da pesquisa qualitativa, a experiência de profissionais de saúde frente à tentativa de suicídio em crianças e adolescentes. Por meio das vivências relatadas pelos profissionais foi possível conhecer o significado atribuído por eles ao fenômeno estudado, além de nos permitir identificar as ações e estratégias desenvolvidas por eles no atendimento à tentativa de suicídio de crianças e adolescentes, além dos principais fatores que influenciam a tentativa de suicídio de crianças e adolescentes.

É difícil finalizar uma pesquisa com tais objetivos sem experienciar relevantes mudanças no modo de pensar e agir perante o fenômeno do suicídio em crianças e adolescentes. Realizar uma pesquisa qualitativa é um desafio, visto que ela permeia experiências e significados, conceitos subjetivos e para os quais o pesquisador precisa encontrar evidências para explicá-los. É um desafio também falar de um problema de saúde pública como é o suicídio e mais ainda quando este acontece na infância ou adolescência, visto ser este um tema permeado por tabus, estigmas e influências socioculturais, religiosas e morais.

O desenvolvimento desta pesquisa possibilitou a reflexão a respeito de vários fatores que envolvem $\mathrm{o}$ atendimento à tentativa de suicídio de crianças e adolescentes, como as crenças e os valores, e pôde ser construído à luz do Interacionismo Simbólico, o qual ajudou a entender a interação entre profissionais de saúde, criança, adolescente e sua família, sendo esta essencial para a recuperação da criança e do adolescente no domicílio.

Nesse contexto, ouvir os profissionais que recebem uma criança e/ou adolescente que tentou o suicídio trouxe inúmeras colocações, desde o que esta experiência significa para eles até suas necessidades e anseios.

Foi possível identificar os principais fatores que predispõem crianças e adolescentes a tentar o suicídio, pois os conhecendo podemos descrever as medidas e fatores protetores para o suicídio, a exemplo do estabelecimento de uma dinâmica familiar saudável, com a presença de qualidade dos pais, com menos acesso à internet e com mais empatia entre crianças e adolescentes. 
Muitas são dificuldades que o profissional de saúde enfrenta nos serviços, principalmente serviços públicos de assistência à saúde, porém, em se tratando de casos de saúde mental na população infanto juvenil, é necessário um destaque por parte das instituições, que precisam oferecer capacitações aos profissionais de maneira a atender suas necessidades e demandas.

$\mathrm{Na}$ perspectiva do atendimento às crianças e adolescentes em tentativa de suicídio, o enfermeiro enfrenta o desafio que vai além de salvar a vida desses pacientes, mas que também compreende o acolhimento e o cuidado para com essa população e sua família.

Atualmente, a enfermagem está engajada na campanha Nursing Now, uma iniciativa da Organização Mundial de Saúde e do Conselho Internacional de Enfermeiros cujo propósito é chamar a atenção dos governos dos países integrantes da ONU, para que valorizem os profissionais de enfermagem, que são essenciais para atingir as metas globais, nacionais e locais de saúde. Frente a isso, é notório que as instituições reconheçam o papel da enfermagem no cuidado às crianças e aos adolescentes que tentaram o suicídio, bem como às suas famílias, visto ser o enfermeiro o profissional que passa mais tempo próximo ao paciente e com o qual famílias inteiras se apoiam.

Deve-se destacar que este estudo foi o primeiro realizado no Brasil abordando a temática sobre o atendimento às crianças e adolescentes em tentativa de suicídio no departamento de emergência infantil. Os resultados evidenciaram que em um ambiente imprevisível, como o pronto-socorro infantil, onde a qualquer momento os profissionais de saúde podem ter de interromper suas atividades para atender a uma emergência, é indispensável que haja diálogo entre o profissional, as famílias e as crianças e adolescentes que estão sendo atendidos. Explicar de forma clara e compreensiva, ouvir e dar atenção são atitudes extremamente importantes, pois a comunicação inadequada e a falta de um feedback podem contribuir para o sofrimento das crianças, dos adolescentes e dos familiares. 


\section{Limitações do estudo}

Como limitação desde estudo, apontamos a coleta de dados ser realizada apenas em um hospital. Por conseguinte, mais pesquisas sobre o tema devem ser conduzidas em instituições públicas e privadas, principalmente no Brasil, para que sejam conhecidas suas realidades e especificidades e para que medidas preventivas para o suicídio em crianças e adolescentes sejam traçadas e difundidas entre as famílias, os serviços de saúde e as escolas.

\section{Aplicações para a prática clínica}

A partir do conhecimento que já existe sobre o atendimento às crianças e adolescentes em tentativa de suicídio no pronto-socorro infantil, o profissional de saúde enfrenta o desafio que vai além de salvar a vida desses pacientes, considera também a importância do acolhimento a essa população e sua família. Nesse sentido, surge a possibilidade de realizar, junto à equipe multiprofissional, fórum de discussões científicas que viabilizem ações para o melhor atendimento e de forma abrangente, mas individualizada, as necessidades de crianças e adolescentes em tentativa de suicídio.

A expertise da equipe que avalia o paciente é fundamental para que o resultado da avaliação da situação permita a criação de um plano individualizado e adequado a cada criança e adolescente. O conhecimento técnico científico sobre características do desenvolvimento da criança e do adolescente, habilidades de comunicação com a criança, adolescente e família promovem uma avaliação de melhor qualidade, assim como empatia, comprometimento profissional, ausência de julgamento e desconstrução de pré-conceitos promovem melhor vínculo com a criança, adolescente e família.

Desse modo, acreditamos que esse trabalho possa colaborar para o aprendizado nesse âmbito e contribuir para intervenções de saúde, visando minimizar o sofrimento de crianças e adolescentes em tentativa de suicídio e suas famílias. 
REFERÊNCIAS BIBLIOGRÁFICAS 


\section{REFERÊNCIAS}

Alves GL, Ferreira RM. O bullying no ambiente escolar. Revista Saúde e Meio Ambiente. 2019; 9(3):82-96.

American Psychiatric Association. Practice guideline for the assessment and treatment of patients with suicidal behaviors. Am J Psychiatry. 2003; 160(11):1-60.

Antai-Otong D. What every ED nurse should know about suicide risk assessment. Journal of Emergency Nursing. 2016; 42(3):199-200.

Araújo LC; Vieira K; Coutinho M. Ideação suicida na adolescência: um enfoque psicossociológico no contexto do ensino médio. Psico-USF. 2010; 15(1):47-57.

Araújo AS, Comassetto I, Tenório AQ, Da Silva RKS, Pessoa IR, Vieira DS, Viana MER. Interfaces on the suicide idea among universities in the health field: an integrative review. Braz. J. of Develop. 2020; 6(3):9610-9602.

Asevedo E, Ziebold C, Diniz E, Gadelha A, Mari J. Ten-year evolution of suicide rates and economic indicators in large Brazilian urban centers. Current Opinion in Psychiatry. 2018; 31(1): 265-71.

Bertolote JM, Mello-Santos C, Botega NJ. Detecção do risco de suicídio nos serviços de emergência psiquiátrica. Rev Bras Psiquiatr [Internet]. 2010; 32; Supl 2:S87-S95.

Blumer H. Symbolic Interactionism: perspective and method. New Jersey: Pearson Prentice Hall; 1969.

Botega NJ. Comportamento suicida: epidemiologia. Psicologia USP. 2013; 25(3):231-236.

Boyatzis RE. Transforming qualitative information: thematic analysis and code development. Thousand Oaks: Sage; 1998.

Braga LL, Dell'Aglio DD. Suicídio na adolescência: fatores de risco, depressão e gênero. Contextos Clínicos. 2013; 6(1).

Braun V, Clarke V. Using thematic analysis in psychology. Qual Res Psychol, 2006; 3(2):77-101.

Brasil. Ministério da Saúde, Organização Pan-Americana da Saúde: Estratégia Nacional de Prevenção do Suicídio. Manual dirigido a profissionais das equipes de saúde mental. Brasília; 2006 [acesso em 2018 jan 18]. Disponível em: https://www.cvv.org.br/wpcontent/uploads/2017/05/manual prevencao suicidio profissionais saude.pdf 
Brasil. Ministério da Saúde, Departamento de Informática do SUS. Indicadores de mortalidade. Óbitos por suicídio por unidade de federação segundo região. Brasília; 2011 [acesso em 2018 jan 18]. Disponível em: http://tabnet.datasus.gov.br/cgi/tabcgi.exe?idb2012/c09.def.

Brasil. Ministério da Saúde. Conselho Nacional de Saúde. Resolução n. 466, de 12 de dezembro de 2012. Estabelece diretrizes e normas regulamentadoras de pesquisas envolvendo seres humanos. In: Diário Oficial da União. Brasília; 2013. p.59.

Brasil. Ministério da Saúde. Agenda de Ações Estratégicas para a Vigilância e Prevenção do Suicídio e Promoção da Saúde no Brasil: 2017 a 2020 . Brasília; 2017.

Brasil. Diário Oficial da União. Lei n 13.819 de 26 de abril de 2019. Institui a Política Nacional de Prevenção da Automutilação e do Suicídio. Diário Oficial da União, Brasília, DF, 29 abr. 2019. Seção 1. p. 1. 2019a. Disponível em: http://www.planalto.gov.br/ccivil 03/ Ato2019-2022/2019/Lei/L13819.htm\#art11

Brasil. Ministério da Mulher, da Família e dos Direitos Humanos. O Suicídio e automutilação tratados sob a perspectiva da família e do sentido da vida. Brasília: 2019b. 53p. Disponível em: https://www.mdh.gov.br/navegue-portemas/observatorio-nacional-da-familia/estudo-o-suicidio-e-a-automutilacao-tratadossob-a-perspectiva-da-familia-e-do-sentido-da-vida

Carmona-Navarro MC, Pichardo-Martínez MC. Atitudes do profissional de enfermagem em relação ao comportamento suicida; influência da inteligência emocional. Rev Latino-am Enfermagem. 2012; 20(6):1161-1168.

Charon JM. Symbolic Interactionism: an introduction, an interpretation, an integration. $10^{\mathrm{a}}$ ed. New Jersey: Pearson Prentice Hall; 2009.

Collado JP, Collado TP, Collado MA, Martínez GM. Intento suicida en adolescentes, un problema de salud em la comunidade. Rev Cuba invest bioméd. 2014; 33(1):1-8.

Cluver L, Orkin M, Boyes ME, Sherr L. Child and adolescent suicide attempts, suicidal behavior, and adverse childhood experiences in South Africa: a prospective study. Journal of Adolescent Health. 2015; 57:52-9.

Creswell JW. Investigação qualitativa e projeto de pesquisa: escolhendo entre cinco abordagens. $3^{\mathrm{a}}$ ed. Porto Alegre: Penso; 2014. 342 p.

Czyz EK, King CA. Longitudinal trajectories of suicidial ideation and subsequent suicide attempts among adolescents inpatients. J Clin Child Adolesc Psychol. 2015; 44(1):181-93. 
Dantas CC, Leite JL, Lima SBS, Stipp MAC. Teoria Fundamentada nos dadosaspectos conceituais e operacionais: metodologia possível de ser aplicada na pesquisa em enfermagem. Rev Latino-am Enfermagem. 2009; 17(4).

De Abreu KP, Lima MADS, Kohlrausch E, Soares JF. Comportamento Suicida: fatores de risco e intervenções preventivas. Rev. Eletr. Enf. [Internet]. 2010; 12(1):195-200. Disponível em: http://www.fen.ufq.br/revista/v12/n1/v12n1a24.htm

De Sá ACA, Medeiros MFN, Diniz ERS, Silva, MLN, Medeiros SS. Percepções dos profissionais de enfermagem acerca do cuidar do paciente suicida. Fiep Bulletin. 2012; 82 (Special Edition - article II).

De Sousa GS, De Santos MSP, Silva ATP, Perrelli JGA, Sougey EB. Revisão de literatura sobre suicídio na infância. Ciência \& Saúde Coletiva. 2017; 22(9):30993110.

Dos Santos LZ, Leão-Machado FC. Suicídio na adolescência: uma revisão sistemática. Revista Uningá. 2019; 56(1):89-98.

Feinberg T, Robey N. Cyberbullying: intervention and prevention strategies. National association of school psychologists. 2010 [acesso em 2017 jan 26]. Disponível em: file:///C:/Users/8861896.ENFUSP/Downloads/15-1 S4-15\%20(1).pdf

Fernández AH, Santana LS, Sánchez AD. Aspectos psicosociales y epidemiológicos vinculados a La conducta suicidas en pacientes de edad pediátrica. Revista Electrôn. $2014 ; 39(4): 1-6$.

Ferrara $P$, lanniello $F$, Cutrona C, Quintarelli F, Vena F, Volgo V et al.. A focus on recent cases of suicides among italian children and adolescentes and a review of literature. Italian Journal of Pediatrics. 2014; 40(69):1-5.

Freitas APA, Borges LM. Tentativas de suicídio e profissionais de saúde: significados possíveis. Estud pesqui psicol. 2014; 14(2): 560-77.

Freuchen A, Grøholt B. Characteristics of suicide notes of children and Young adolescents: an examination of the notes from suicide victims 15 years and younger. Clin Child Psychol Psychiatry. 2015; 20(2):194-206.

Hauser M, Galling B, Correll CU. Suicidal ideation and suicide attempts in children and adolescents with bipolar disorder: a systematic review of prevalence and incidence rates, risk factors, and targeted interventions. Bipolar Disord. 2013; 15(5):507-23.

Heck RM, Kantorski LP, Borges AM, Lopes CV, Santos MC, Pinho LB. Ação dos profissionais de um centro de atenção psicossocial diante de usuários com tentativa e risco de suicídio. Texto Contexto Enferm. 2012; 21(1):26-33. 23. 
Jaen-Varas D, Mari Jair, Asevedo E, Borschmann R, Diniz E, Ziebold C et al. The association between adolescent suicide rates and socioeconomic indicators in Brazil: a 10-year retrospective ecological study. Braz. J. Psychiatry. 2019; 41(5):389-395.

Jans T, Vloet TD, Taneli Y, Warnke A. Suicidio y conducta autolesiva. In: Rey JM (ed). Manual de Salud Mental Infantil y Adolescente de la IACAPAP. Ginebra: Asociación Internacional de Psiquiatría Del Niño y el Adolescente y Profesiones Afines, 2017.

Koenig J, Brunner R, Waldschmidt GF, Parzer P, Plener PL, Park JY et al. Prospective risk of suicidal thoughts and behavior in adolescents with onset, maintenance or cessation of direct self-injury behavior. Eur Child Adolesc Psychiatric. $2017 ; 26: 345-54$.

Kõlves K, De Leo D. Suicide methods in children and adolescents. Eur Child Adolesc Psychiatr. 2017; 26(2):155-164.

Kuczynski E. Suicídio na infância e adolescência. Psicologia USP. 2014; 25(3): 24652.

Lévesque SM, Ryan NC, Parent S, Renaud J, Vitaro F, Boivin M et al. Victimization, suicidal ideation, and alcohol use from age 13 to 15 years: support for the selfmedication model. J Adolesc Health. 2017; 60(4):380-7.

Lieberman R, Cowan KC. Bullying and youth suicide: breaking the connection. National Association of School Psychologists. 2011 [acesso em 2017 jan 26]. Disponível file:///C:/Users/8861896.ENFUSP/Downloads/Bullying Suicide Oct2011.pdf

em:

López JLB, Malaver VMO, Murga HBV, Falconí LH. Prevalencia y factores asociados com La conducta suicida en adolescentes de Lima rural. Rev Neuro psiquiatr. 2016;79(1): 3-15.

Minayo MCS. O desafio do conhecimento: pesquisa qualitativa em saúde. $14^{\mathrm{a}}$ ed. São Paulo: Hucitec, 2014. 406 p.

Navarro CC, Martínez CP. Atitudes do profissional de enfermagem em relação ao comportamento suicida: influência da inteligência emocional. Rev LatinoAm.Enfermagem. 2012; 20(6):1-8.

$\mathrm{Ng}$ LC, Kirk CM, Kanyanganzi F, Fawzi MCS, Sezibera V, Shema E, Bizimana JI, Cyamatare FR, Betancourt TS. Risk and protective factors for suicidal ideation and behaviour in Rwandan children. The British Journal of Psychiatry. 2015;207:262-268.

Organização Mundial da Saúde. Preventing suicide: a global imperative. 2014 [acesso em 2018 jan 18]. Disponível em: http://apps.who.int/iris/bitstream/10665/131056/1/9789241564779 eng.pdf 
Pereira WKS, Maciel MPGS, Guilhermino GMS. O adolescente que tenta suicídio: estudo epidemiológico em unidades de referência. J Nurs UFPE online. 2017; 11(8):3130-5.

Pfeffer CR. Childhood suicidal behavior: a developmental perspective. Psychiatr Clin North Am. 1997; 20(3):551-562.

Polit DF, Beck CT. Fundamentos de Pesquisa em Enfermagem: avaliação de evidências para a prática da enfermagem. $7^{\text {a }}$ ed. Porto Alegre: Artmed; 2011.

Rasmussen $\mathrm{CH}$, Martín AHS. Comportamientos de riesgo de suicídio y calidad de vida, por género, em adolescentes mexicanos, estudiantes de preparatoria. Ciência \& Saúde Coletiva. 2015; 20(11):3437-45.

Reisdorfer N, Araujo GM, Hildebrandt LM, Gewehr TR, Nardino J, Leite MT. Suicídio na voz de profissionais de enfermagem e estratégias de intervenção diante do comportamento suicida. Rev Enferm UFSM. 2015; 5(2): 295-304.

Ribeiro AA, De Carvalho CMSM, Shubert CO, Barreto CTG, Nunes AS, Natale JCO. O Enfermeiro e a pessoa que tenta suicídio: Uma reflexão do cuidado humanizado. Ciência Atual. 2018; 11(1): 2-15.

Rubin HJ, Rubin IS. Qualitative Interviewing: the art of hearing data. California: Thousands Oaks; Sage Publications: 2012.

Sandelowski M, Leeman J. Writing usable qualitative health research findings. Qual Health Res. 2012; 22(10):1404-1413.

Santos MS, Coimbra VCC, Ribeiro JP. Attending emergency psychiatric held by the nurse of the service móbile emergency. Revista de Enfermagem UFPE online. 2011; 5(9):2197-2205.

Santos AS, Legay LF, Lovisi GM. Substâncias tóxicas e tentativas e suicídios: considerações sobre acesso e medidas restritivas. Cadernos Saúde Coletiva. 2013; 21(1):53-61.

Silva CAM, Gomes JC, Amaral MS, Loreto RGO. Atuação do profissional enfermeiro no atendimento ao paciente por tentativa de suicídio. Revista Científica FacMais. 2017; 9(2):27-40.

Silva LLT, Alvim CG, Costa CC, Ramos TM, Costa EE. O Suicídio na adolescência nas publicações da enfermagem brasileira: Revisão Integrativa da Literatura. R. Enferm. Cent. O. Min. 2015; 5(3):1871-84.

Silva L, Afonso BQ, Santos MR, Baliza MF, Rossato LM, Szylit R. Care for families after suicide loss: nursing academic experience. Rev Bras Enferm. 2018; 71(Suppl 5):2206-12. 
Silva L. Suicídio entre crianças e adolescentes: um alerta para o cumprimento do imperativo global. Acta paul. enferm. [Internet]. 2019; 32( 3 ): III-IVI.

Soole R, Kolves K, De Leo D. Suicide in Children: a Systematic Review. Arch Suicide Res. 2015; 19(3):285-304.

Souza LDM, Ores L, Oliveira GT, Cruzeiro ALS, Silva RA, Pinheiro RT, Horta BL. Ideação suicida na adolescência: prevalência e fatores associados. J Bras Psiquiatr. 2010; 59(4):286-292.

Sullivan SA, Lewis G, Gunnell D, Cannon M, Mars B, Zammit S. The longitudinal association between psychotic experiences, depression and suicidal behavior in a population sample of adolescent. Soc Psychiatry Epidemiol. 2015; 50:1809-17.

Thomas DA. General inductive approach for analyzing qualitative evaluation data. American Journal of Evaluation. 2006; 27:237-246.

Thorne S, Kirkham S, MacDonald-Emes J. Focus on qualitative methods interpretative description: a non-categorical qualitative alternative for developing nursing knowledge. Research in Nursing \& Health. 1997; 20:169-177.

Trujillo AH, Elías IEG, Acosta YML. Factores de riesgo relacionados com La conducta suicida em la infância y adolescência. MEDISAN. 2013; 17(12):9027-35.

Vaismoradi $\mathrm{M}$, Turunen $\mathrm{H}$, Bondas $\mathrm{T}$. Content analysis and thematic analysis: implications for conducting a qualitative descriptive study. Nursing and Health Sciences. 2013; 15:398-405.

Vannoy SD, Tai-Seale M, Duberstein P, Eaton LJ, Cook MA. Suicide ideation respondes in late-life primary care. Journalof General Internal Medicine. 2011; 26(9):1005-1011.

Vaz-Tostes JS, Machado MCL, Da Cunha LR, Chaves ACM. Clinical-epidemiologic profile of suicidal behavior at a Psychiatric Emergency Service of Infant and Adolescent in Belo Horizonte. Revista Interdisciplinar Ciências Médicas. 2019; 3(2): 23-29.

Vieira LP, Santana VTP, Suchara EA. Caracterização de tentativas de suicídios por substâncias exógenas. Cadernos Saúde Coletiva. 2015; 23(2):118-123.

Waiselfisz JJ. Mapa da violência 2014. Rio de Janeiro; Flacso Brasil; 2014 [acesso em 2018 jan 18]. Disponível em: http://www.mapadaviolencia.org.br/mapa2014 jovens.php 
ANEXOS 


\section{ANEXO 1 \\ Aprovação do Comitê de Ética em Pesquisa da Escola de Enfermagem da Universidade de São Paulo}

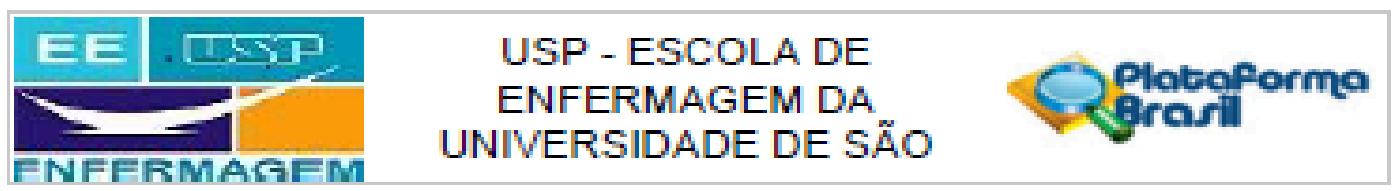

\section{PARECER CONSUBSTANCIADO DO CEP}

\section{DADOS DO PROJETO DE PESQUISA}

Titulo da Pesquisa: Compreendendo a experiencla de pronssionals da saude trente a tentativa de suicidlo de crianças e adolescentes.

Pesqulasdor: Uszbele Mariano Rossato

Area Tematica:

Versato: 1

CAAE: 90302018.6 .0000 .5392

Institulçaso Proponente: Escola de Enfermagem da Universidade de Săo Paulo - EEUSP

Patrocinador Principal: Financlamento Proprio

\section{DADOS DO PARECER}

Número do Parecer: 2.712 .870

Apreeentaça do Projeto:

Trata-se de uma pesquisa qualtativa a ser realizada com medicos, enfermelros, tecnicos de enfermagem e assistertes socials nos prontos-socorros infantll e aduito de um hospital publico de ensino no municiplo de Săo Paulo, que tem como oojetivo compreender a experiencla de profissionals da saude trente a tentativa de sulcidlo de crianças e adolescentes.

Os referenclals teoricos e metodologicos serăo, respectivamente, o Interacionismo Simbolico e a Teoria Fundamentada nos Dados.

A estrategla adotada para a coleta de dados sera a entrevista semiestruturada agendada pessoaimente com cada pronssional que escolhera o melhor dla e horario para sua real zaçálo.

A entrevista tera como foco de atençấo a compreensăo da experiencla de pronissionals da saude frente a tentativa de sulcido de crianças e adolescentes, sendo norteadoras as seguintes perguntas:

"Conte-me uma experlencla que voce tenha vivenclado com crianças ejou adolescentes em tentativa de sulcidio"

"Como e para voce atender uma criança elou adolescente em tentatva de sulcido?"

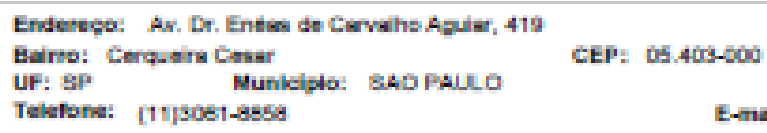




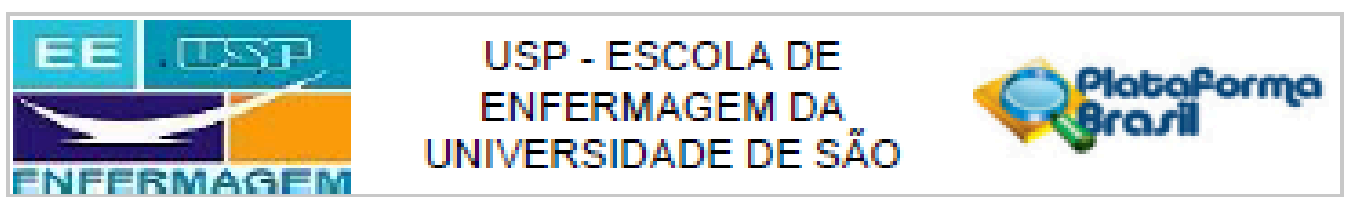

Conthuabla to panoar 2712 mo

Tœdas as entrevstas serdo gravadas, medlante autorzaçăo dos partıcipantes com a assinatura do TCLE, e posteriormente transcritas na integra.

A analse dos dados sera simultanea a coleta de dados e começara com a codincaçăo aberta na qual, a partir de uma leltura exaustiva das entrevistas, serda formados codigos Iniclals de informaçăo sobre o fenomeno estudado, posteriormente comparados e agupados em categorlas por simlandade de sigrificado.

Objetlvo da Psequlsa:

Objettvo Gera: Compreender a experiencla de pronssionals da saude trente a tentativa de sulcidlo de crianças e adolescentes.

Objetvos Especifcos: Compreender os significados atribuldos pelos profissionals da saude a tentativa de sulcidlo de crianças e adolescentes; Identincar as açbes e estrateglas desenvolvidas pelos profsslonals da saude no atendimento a tentativa de sulcido de crianças e adolescentes; Desenvolver um modelo tecrico explicativo do signincado da experiencla de pronssionals da saude frente a tentattva de sulcidlo de crianças e adolescentes.

Avallaça dos Flscos $\theta$ Benenclos:

Fiscos: desconforto ao participante no momento da entrevista. Durante a real zaçăo das entrevistas, a pesquisadora ficara atenta a qualquer manifestaçăo de mal-estar e sotimento por parte participante, proporcionando escuta sensivel dlante do sofrimento que possa ter sido gerado. Persistindo esse sofrimento, o participante sera encaminhado ao serviço de psiqulatria e psicologla da institulçăo. Beneficlos: Este estudo pode năo trazer beneficlos diretos e Imediatos, mas ajudara os profisslonals entenderem melhor como se da $o$ atendimento a criança e ao adolescente em tentativa de sulcidlo.

Comentarios $\theta$ Consideraç0es sobre a Pesqulsa:

Pesquisa desenvolvida atraves de orçamento proprio.

Cronograma apresentado e compativel com o desenvolvimento do estudo.

Tenatca relevante.

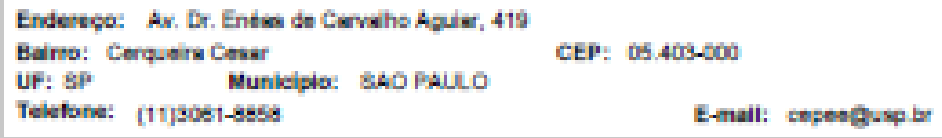




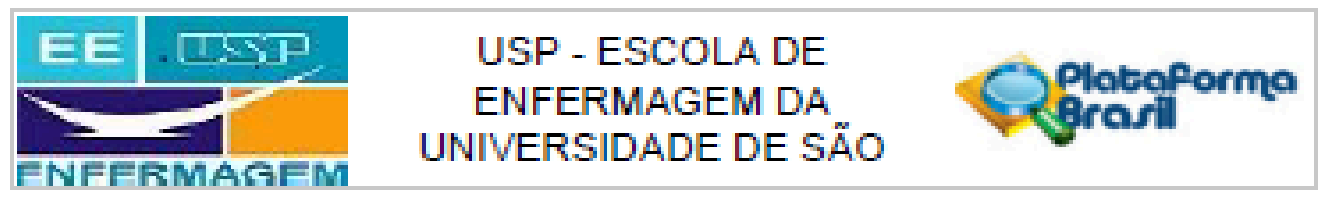

Conthackla to pancer: 2712 ano

Consideraç6s sobre os Termos de apresentaça obrigatorla:

Fol apresentado TCLE en contormidade com a Resoluç50 466 de 2012

\section{Recomendaços:}

Sem Recomendaçbes.

Conclusber ou Pendenclas $\theta$ Llata de Inadequascoes:

Ausencla de colces etlcos.

Consideraços Finals a criterio do CEP:

Este CEP Informa a necessldade de registro dos resultados parcials e fnals na Plataforma Erasll. Esta aprovaçăo nåo substitul a autorizaçăo da Institulçăo coparticlpante, antes do Inlcio da coleta de dados.

Este parecer fol elaborado bsesado nos documentos abalxo relacionados:

\begin{tabular}{|c|c|c|c|c|}
\hline Tipo Documento & Arquivo & Postagem & Autor & Situ.usç50 \\
\hline $\begin{array}{l}\text { Intomaçoes Basicas } \\
\text { do Proleto }\end{array}$ & $\begin{array}{l}\text { PE_INFOFWACQOES_BASICAS_DO_P } \\
\text { ROJETO 1134169.pơ }\end{array}$ & $\begin{array}{c}2405 / 2018 \\
16: 10: 37\end{array}$ & & Acerto \\
\hline Qutros & Dedarac30Benetclos.pdt' & $\begin{array}{c}24 / 05 / 2018 \\
16: 09: 29\end{array}$ & $\begin{array}{l}\text { Uszbele Mariano } \\
\text { Rossato }\end{array}$ & Acelio \\
\hline Qutros & Cadastrodep rotocolodepesquisa.por' & $\begin{array}{c}2405 / 2018 \\
16: 08: 55\end{array}$ & $\begin{array}{l}\text { Usabele Mariano } \\
\text { Rossato }\end{array}$ & Acelito \\
\hline Outros & CartadeAnuenda.pd" & $\begin{array}{c}24 / 05 / 2018 \\
16: 08: 29\end{array}$ & $\begin{array}{l}\text { Usabele Mariano } \\
\text { Rossato }\end{array}$ & Acelto \\
\hline Cronograma & Cronograma.pot' & $\begin{array}{c}2405 / 2018 \\
16: 06: 39\end{array}$ & $\begin{array}{l}\text { Usabele Mariano } \\
\text { Rossato }\end{array}$ & Acelto \\
\hline $\begin{array}{l}\text { Dediaraça de } \\
\text { Pesquisadores }\end{array}$ & $\begin{array}{l}\text { Declaracaodecompromissodopesquisad } \\
\text { or.pdif }\end{array}$ & $\begin{array}{c}24 / 05 / 2018 \\
16: 05: 26\end{array}$ & $\begin{array}{l}\text { Usabele Mariano } \\
\text { Rossato }\end{array}$ & Acelto \\
\hline $\begin{array}{l}\text { Dedaraça de } \\
\text { Institulçato e } \\
\text { Intraegtutura }\end{array}$ & Deciaracaolnfraestrutura.pd" & $\begin{array}{c}24 / 05 / 2018 \\
16: 06: 12\end{array}$ & $\begin{array}{l}\text { Usabele Mariano } \\
\text { Rossato }\end{array}$ & Acelto \\
\hline Orçamento & Orcamento.pd" & $\begin{array}{c}24 / 05 / 2018 \\
16: 05: 54\end{array}$ & $\begin{array}{l}\text { Usabele Mariano } \\
\text { Rossato }\end{array}$ & Acelito \\
\hline $\begin{array}{l}\text { Projeto Detalhado? } \\
\text { Brochura } \\
\text { Investigador }\end{array}$ & ProjetoCEP.dOCX & $\begin{array}{c}2405 / 2018 \\
16: 05: 32\end{array}$ & $\begin{array}{l}\text { Uszbele Mariano } \\
\text { Rossato }\end{array}$ & ACETOD \\
\hline $\begin{array}{l}\text { TCLE / Termos de } \\
\text { Assentimento I } \\
\text { Justuncativa de } \\
\text { Ausencla }\end{array}$ & TCLE.docx & $\begin{array}{c}24 / 05 / 2018 \\
16: 05: 11\end{array}$ & $\begin{array}{l}\text { Uszbele Mariano } \\
\text { Rossato }\end{array}$ & Acelto \\
\hline Folna de Rosto & Folhaderostozssinada.pd" & $\begin{array}{c}24 / 05 / 2018 \\
16: 04: 38\end{array}$ & $\begin{array}{l}\text { Lsabele Mariano } \\
\text { Rossato }\end{array}$ & Acelito \\
\hline
\end{tabular}

Endesep̧o: Av. Dr. Entwo de Crevelhe Aguier, 419

Balmo: Cerquains Conser

UF: SP Municiglo: BAD PALLO

CEP: $05.403-000$

Teleforie: [11]9oet-8esa

E-mall: cosengusp be 


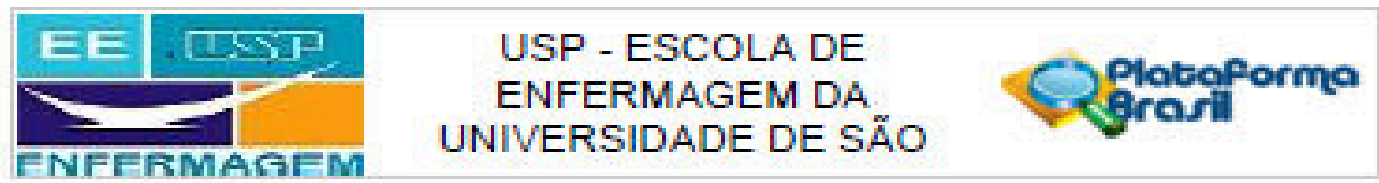

Conthacks de panoar: $2712 \mathrm{~kg}$

situaça do Parecer:

Aprovado

Necesalta Apreclaçao da CONEP:

Naือ

SAO PAULO, 14 de Junho de 2018

Assinado por:

Marcla Aparecida Ferreira de Ollvelra

(Coordenador)

Enderego: Ar. Dr. Entra de Crvelhs Aguier, 419

Barno: Cerquain Cesar

CEP: of $403-000$

UF: Sp Municiplo: sap palico

Telefore: [11]90e]-8ese

E-mall: copeogus b

nomication 
ANEXO 2

Aprovação do Comitê de Ética em Pesquisa da Instituição Coparticipante

USP - HOSPITAL
UNIVERSITÁRIO DA
UNIVERSIDADE DE SÃO

\section{PARECER CONSUBSTANCIADO DO CEP}

Elaborado pela Institulçäso Coparticipante

\section{DADOS DO PROJETO DE PESQUISA}

Titulo da Pesqulsa: Compreendendo a experiencla de profissionals da saude trente a tentativa de sulcido de crianças e adolescentes.

Peequlsador: Uszbele Mariano Rossato

Area Tematica:

Versas: 1

CAAE: 90302018.6 .3001 .0076

Institulçäo Proponente: Hospital Unlversitario da Unlversidade de Săo Paulo

Patrocinador Principal: Financlamento Proprio

\section{DADOS DO PARECER}

Nümero do Parecer: 2.778 .446

Apreeentaça do Projeto:

O sulcidlo, fenomeno complexo e murticausal, no qual o indviduo provoca sua propria morte, e considerado, nos dias atuals, um problema de saude publca mundal que atinge todas as falxas etarlas.A tematica do sulcidlo em crianças e adolescentes envolve năo apenas as famllias, mas tambem os profissionals da saude, visto que o número de tentativas esta cada vez mais crescente no cotidiano dos serviços de urgencla e emergencla. Porem, os significados que os pronssionals atribuem as expentenclas frente as tentativas de sulcidlo de crianças e adolescentes podem Influenclar na qualldade dos atendimentos. Diante disso, a seguinte questăo de pesquisa fol formuladax "Qual e a experiencla dos profissionals da saude frente a tentativa de sulcidlo de crianças e adolescentes?".

\section{Objetlvo da Pesqulsa:}

Objettvo geral: Compreender a experiencla de profissionals da saude frente a tentativa de sulcidlo de crianças e adolescentes.

Objetvos especificos: Compreender os significados atribuldos pelos protissionals da saude a tentativa de sulcido de crianças e adolescentes;

Identificar as açbles e estrategias desenvolvidas peios protssionals da saude no atendimento a tentativa de sulcidlo de crianças e adolescentes.

Desenvolver um modelo teorico explicativo do significado da experiencla de profissionals da

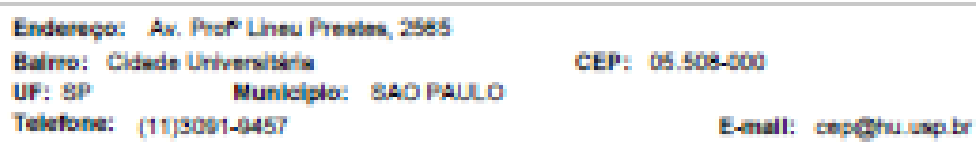




\section{USP - HOSPITAL \\ UNIVERSITÁRIO DA UNIVERSIDADE DE SÃO}

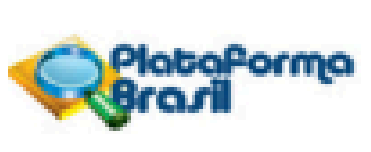

Conthackla to Pamoar 2 mo we

saude frente a tentativa de sulcidlo de crianças e adolescentes.

Avallaça dos Rlacos $\theta$ Benenclos:

Pesquisa năo apresenta riscos.

Beneficlo potenclal de compreender como a tematica da tentatva de sulcidlo em crianças e adolescentes afeta 06 pronssionals de saude envolvidos no atendimento.

Comentarios $\theta$ Consideraç0es sobre a Pesqulsa:

Pesquisa adequada e relevante em seu campo.

Consideraç5es sobre 08 Termos de apresentaçâ obrigatorla:

Presentes e adequados.

Recomendaçoes:

Sem recomendaçes.

Conclusder ou Pendenclas $\theta$ Llata de Inadequsçoes:

Sem pendenclas ou inadequaçbes.

Consideraçoes Finals a criterlo do CEP:

Este parecer fol elaborado bseesdo nos documentos abalxo relacionados:

\begin{tabular}{|c|c|c|c|c|}
\hline Tipo Documento & Arquivo & Postagem & Altor & Stuaç50 \\
\hline $\begin{array}{l}\text { Dedaraça de } \\
\text { Instutuçatoe } \\
\text { Intraegtutura }\end{array}$ & $\begin{array}{l}\text { Anuencla_Resplegal_Pesq_Lsabelle.p } \\
\text { d̛ }\end{array}$ & $\begin{array}{c}22 / 06 / 2018 \\
14: 41: 59\end{array}$ & $\begin{array}{l}\text { Wima Montelro } \\
\text { Fresca }\end{array}$ & Acelito \\
\hline Outros & Anuencia_CPesq_Lsabele.pdf & $\begin{array}{c}22 / 06 / 2018 \\
14: 41: 39\end{array}$ & $\begin{array}{l}\text { Wima Montelro } \\
\text { Fresca }\end{array}$ & Acelito \\
\hline Outros & CacastroHU_Pesq_Lsabele.pot & $\begin{array}{c}2200 / 2018 \\
14: 41: 08\end{array}$ & $\begin{array}{l}\text { Whima Montelo } \\
\text { Fresca }\end{array}$ & Aceito \\
\hline Outros & DeclaracaoBenetclos.pdt & $\begin{array}{c}24 / 05 / 2018 \\
16: 09: 29\end{array}$ & $\begin{array}{l}\text { Usabele Mariano } \\
\text { Rossato }\end{array}$ & Acelito \\
\hline Otros & Cadasstrodep rotocolodepesquisa. por & $\begin{array}{l}2405 / 2018 \\
16: 08: 55\end{array}$ & $\begin{array}{l}\text { Lstabele Mariano } \\
\text { Rossato }\end{array}$ & Aceitio \\
\hline Outros & CartadeAnuenda.pd' & $\begin{array}{c}24 / 05 / 2018 \\
16: 08: 29\end{array}$ & $\begin{array}{l}\text { Lsabele Mariano } \\
\text { Rossato }\end{array}$ & Acelito \\
\hline $\begin{array}{l}\text { Projeto Detalhado } / \\
\text { Erochura } \\
\text { Investioador }\end{array}$ & ProjetoCEP.docx & $\begin{array}{c}24 / 05 / 2018 \\
16: 05: 32\end{array}$ & $\begin{array}{l}\text { Usabele Mariano } \\
\text { Rossato }\end{array}$ & Acelito \\
\hline $\begin{array}{l}\text { TCLE/Termos de } \\
\text { Assentimento / }\end{array}$ & TCLE.dOCX & $\begin{array}{c}24 / 05 / 2018 \\
16: 05: 11\end{array}$ & $\begin{array}{l}\text { Uszbele Mariano } \\
\text { Rossato }\end{array}$ & Acelito \\
\hline
\end{tabular}

\footnotetext{
Endeseço: Av. Prof Linnu Prewins, ases

Baino: Cldede Universiters

UF: SP Municiplo: SAO paLCo

CEP: 05.508-500

Teleforie: [1119051-345?

E-mall: copchtu usp br
} 


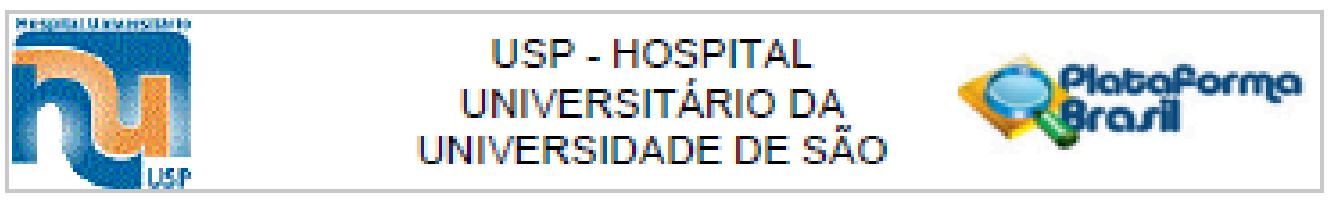

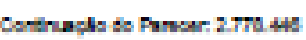

\begin{tabular}{|l|l|c|l|l|}
\hline $\begin{array}{l}\text { Justiflicativa de } \\
\text { Au.sencla }\end{array}$ & TCLE.docx & $\begin{array}{c}24 / 05 / 2018 \\
16: 05: 11\end{array}$ & $\begin{array}{l}\text { Lsabele Mariano } \\
\text { Rossato }\end{array}$ & Acelto \\
\hline
\end{tabular}

sltuaça do Parecer:

Aprovado

Necesalta Apreclaç3o da CONEP:

Nă

SAO PAULO, 20 de Julho de 2018

Assinsdo por:
Maurliclo Seckler
(Coordenador)

Enderege: Av. Prof Linnu Frewan, 2ses

Baino: Cidede Lnivensiters

UF: SPP Munieigio: BAO PALCO

Telefone: [11]3061-945?
CEP: OS.508-600

E-mall: copeth usp br 


\section{APÊNDICES}




\section{APÊNDICE 1}

\section{Termo de Consentimento Livre e Esclarecido}

\section{Prezado profissional}

Meu nome é Danila Maria Batista Guedes e gostaria de lhe convidar a participar de livre e espontânea vontade do estudo "Compreendendo a experiência de profissionais da saúde frente à tentativa de suicídio em crianças e adolescentes", que tem como objetivo compreender a experiência de profissionais da saúde à tentativa de suicídio em crianças e adolescentes. Este estudo pode não lhe trazer benefícios diretos e imediatos, mas lhe ajudará a entender melhor como se dá o atendimento à criança e ao adolescente em tentativa de suicídio. Vou lhe fazer algumas perguntas. A entrevista será gravada digitalmente, terá duração de, aproximadamente, 50 minutos e será sobre sua experiência frente à tentativa de suicídio de crianças e adolescentes. O que o(a) senhor(a) me contar será somente do meu conhecimento, sendo mantido sigilo e respeito a sua privacidade. O relatório final da pesquisa será publicado, sem que seu nome seja mencionado e o (a) senhor(a) poderá desistir de colaborar com a pesquisa em qualquer momento, sem que o(a) senhor(a) tenham qualquer gasto ou prejuízo em seu trabalho no hospital. O (a) senhor(a) também não será pago ou receberá qualquer benefício. No entanto, se tiver despesas decorrentes desta pesquisa, terá direito a ressarcimento por elas. $\mathrm{Se}$ em algum momento esta entrevista lhe trouxer algum desconforto ou constrangimento, poderemos interrompê-la imediatamente e, se for necessário, procuraremos ajuda médica no pronto-socorro. Embora nenhum dano físico ou emocional seja esperado durante ou após a entrevista, se algum dano ocorrer o (a) senhor(a) terá direito à indenização. Em caso de dúvidas o(a) senhor(a) poderá entrar em contato comigo, no endereço: Av. Dr. Enéas de Carvalho Aguiar, 419, CEP 05403-000, São Paulo, SP e pelo telefone (11) 3061-7602 em horário comercial e durante 24h pelo e-mail: danilaguedes@usp.bre/ou com o Comitê de Ética da Escola de Enfermagem da USP: Av. Dr. Enéas de Carvalho Aguiar, 419, CEP 05403-000, São Paulo, SP; e-mail: cepee@usp.br e/ou Fone: (11) 3061-8858 ou ainda com o Comitê de Ética em Pesquisa do Hospital Universitário CEP-HU/USP: Av. Prof. Lineu Pestes, 2565 - Cidade Universitária - CEP: 05508-000 - São Paulo SP - Telefone: (11) 3091-9457 - Fax: (11) 3091-9479 e-mail: cep@hu.usp.br. Este documento será paginado, assinado e rubricado em duas vias, ficando uma via com o(a) senhor(a) e a outra comigo. Esta pesquisa atende todas as especificações da Resolução 466, de 12 de dezembro de 2012, que aprova as diretrizes e normas regulamentadoras de pesquisas envolvendo seres humanos.

Assinatura do profissional

Assinatura do Pesquisador

São Paulo, 


\title{
Ficha do Aluno
}

\author{
Universidade de São Paulo \\ Escola de Enfermagem \\ Documento sem validade oficial \\ FICHA DO ALUNO
}

7141 - 8861896/2 - Danila Maria Batista Guedes

\begin{tabular}{|c|c|c|c|c|c|c|c|c|c|}
\hline Sigla & Nome da Disciplina & Início & Término & $\begin{array}{l}\text { Carga } \\
\text { Horária }\end{array}$ & Cred. & Freq- & Conc. & Exc. & Situação \\
\hline $\begin{array}{l}\text { ENP5870- } \\
4 / 2\end{array}$ & $\begin{array}{l}\text { Pesquisa Quantitativa em Enfermagem na Saúde da Mulher e } \\
\text { Perinatal (1) }\end{array}$ & $03 / 04 / 2015$ & $12 / 06 / 2015$ & 45 & 3 & 100 & A & $N$ & Concluida \\
\hline $\begin{array}{l}\text { ENO5881- } \\
5 / 2\end{array}$ & Metodologia de Pesquisa: Abordagem Qualitativa & $04 / 05 / 2016$ & $12 / 07 / 2016$ & 90 & 6 & 100 & A & $\mathrm{N}$ & Concluida \\
\hline $\begin{array}{l}\text { ENP5945- } \\
\qquad / 1 / 1\end{array}$ & $\begin{array}{l}\text { - A Criança como Sujeito do Cuidado e da Pesquisa: Bases } \\
\text { Téóricas e Metodológicas }\end{array}$ & $11 / 05 / 2016$ & $28 / 06 / 2016$ & 60 & 4 & 100 & A & $N$ & Concluida \\
\hline $\begin{array}{l}\text { EDI5941- } \\
1 / 2\end{array}$ & $\begin{array}{l}\text { Revisâo Sistemática da Literatura: Rigor, Metodologias e Etapas } \\
\text { de Desenvolvimento }\end{array}$ & $28 / 07 / 2016$ & $06 / 10 / 2016$ & 90 & 6 & 90 & A & $N$ & Concluida \\
\hline $\begin{array}{l}\text { ENP5783- } \\
5 / 1\end{array}$ & Familias e Doenças: Pesquisa e Contexto & $02 / 08 / 2016$ & $11 / 10 / 2016$ & 60 & 4 & 100 & A & $\mathrm{N}$ & Concluida \\
\hline $\begin{array}{l}\text { ENP5961- } \\
\qquad 1 / 1\end{array}$ & $\begin{array}{l}\text { - Aspectos Conceituais e Metodológicos da Pesquisa em } \\
\text { Tanatologia }\end{array}$ & $28 / 11 / 2016$ & $05 / 12 / 2016$ & 15 & 1 & 100 & A & $\mathrm{N}$ & Concluida \\
\hline $\begin{array}{l}\text { Atividade } \\
\text { do } \\
\text { Programa }\end{array}$ & $\begin{array}{l}\text { Participou da Etapa de Estágio Supervisionado em Docência do } \\
\text { Programa de Aperfeiçoamento de Ensino junto à disciplina } \\
\text { ENP0382 - Enfermagem no Cuidado à Criança e Adolescente } \\
\text { na Experiência de Doença da Escola de Enfemagem, } \\
\text { ministrada aos alunos dả Graduaçáo do Curso da Escola de } \\
\text { Enfermagem da Universidade de Sâo Paulo. (2) }\end{array}$ & $01 / 02 / 2017$ & $30 / 06 / 2017$ & - & 2 & - & - & - & - \\
\hline$\underset{4 / 3}{\text { ENC5883- }}$ & Prática Pedagógica no Ensino Superior & $07 / 03 / 2017$ & $15 / 05 / 2017$ & 90 & 6 & 90 & A & $N$ & Concluida \\
\hline $\begin{array}{l}\text { ENO5859- } \\
6 / 1\end{array}$ & $\begin{array}{l}\text { - Tecnologias da Informaçào nos Processos de Trabalho na } \\
\text { Saúde e na Enfermagem }\end{array}$ & $04 / 05 / 2017$ & $05 / 07 / 2017$ & 90 & 6 & 88 & A & $\mathrm{N}$ & Concluida \\
\hline $\begin{array}{l}\text { ENP5968- } \\
1 / 1\end{array}$ & $\begin{array}{l}\text { - Evidências em cuidados palativos pediátricos (Curso } \\
\text { Interunidades: Enfermagem - Universidade de Săo Paulo) }\end{array}$ & $05 / 03 / 2018$ & $18 / 03 / 2018$ & 30 & 2 & 100 & A & $\mathrm{N}$ & Concluida \\
\hline
\end{tabular}

\begin{tabular}{|l|cc|c|}
\hline & \multicolumn{2}{|c|}{ Créditos mínimos exigidos } & Créditos obtidos \\
\hline & Para exame de qualificaçäo Para depósito de tese & \\
\hline Disciplinas: & 0 & 28 & 40 \\
\hline Estágios: & 0 & 28 & 40 \\
\hline Total: & & & \\
\hline
\end{tabular}

Observaçôes:

Créditos Atribuídos à Tese: 140

1) Disciplina(s) cursada(s) isoladamente e aceita(s) pelo(a) orientador(a) do(a) candidato(a).

2) Créditos atribuídos de acordo com o disposto na Portaria GR-3588 e GR-4391 - PAE, de 31.08 .09 e aprovados pela Comissäo Coordenadora de Programa, em Sessäo de 02/07/2018.

Conceito a partir de 02/01/1997:
A - Excelente, com direito a crédito; B - Bom, com direito a crédito; C - Regular, com direito a crédito; R - Reprovado; T - Transferência.
Um(1) crédito equivale a 15 horas de atividade programada.

